\title{
Transportation and Packaging Headquarters Support 1997 Multi-Year Work Plan WBS 8.1
}

T. J. Chapman

Date Published

August 1996

Prepared for the U.S. Department of Energy

Assistant Secretary for Environmental Management

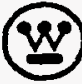




\section{RELEASE AUTHORIZATION}

Document Number: WHC-SP-1187, Rev. 0

Document Title: Transportation and Packaging Headquarters Support 1997 Multi-Year Work Plan WBS 8.1

Release Date: $\quad 8 / 29 / 96$

This document was reviewed following the procedures described in WHC-CM-3-4 and is:

APPROVED FOR PUBLIC RELEASE

WHC Information Release Administration Specialist:

(thio Mullexglame)

$8 / 29 / 96$

c. Wil bihgham 


\begin{tabular}{|c|c|}
\hline \multicolumn{2}{|c|}{ A. Information Category } \\
\hline Speech or Presentation \\
$\square$ Full Paper & $\square$ Journal Article \\
$\square$ summary & $\square$ Multimedia Presentation \\
$\square$ Abstract & $\square$ Software \\
$\square$ visual Aid & \\
$\square$ Other MYWP Tech Repot
\end{tabular}

B. Document ID Number (include rev., vol., etc.)

WHC-SP-1187 Rev. 0

C. List attachments (i.e., copyright permission, copyright transfer)

D. Document Title

Transportation \& Packaging Headquarters Support FY 1997 Multi-Year Work PTan WBS 8.1

E. WHC Project or Program

Transportation

\& Packaging ADS 2601

Richland

Transportation

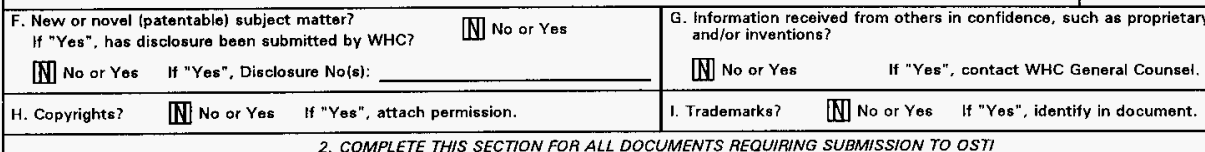

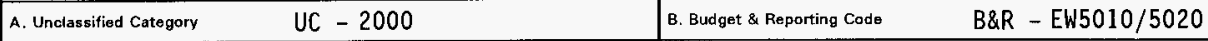

3. COMPLETE THIS SECIION ONL Y FOR A JOURNAL SUBMISSION

A. Title of Journal

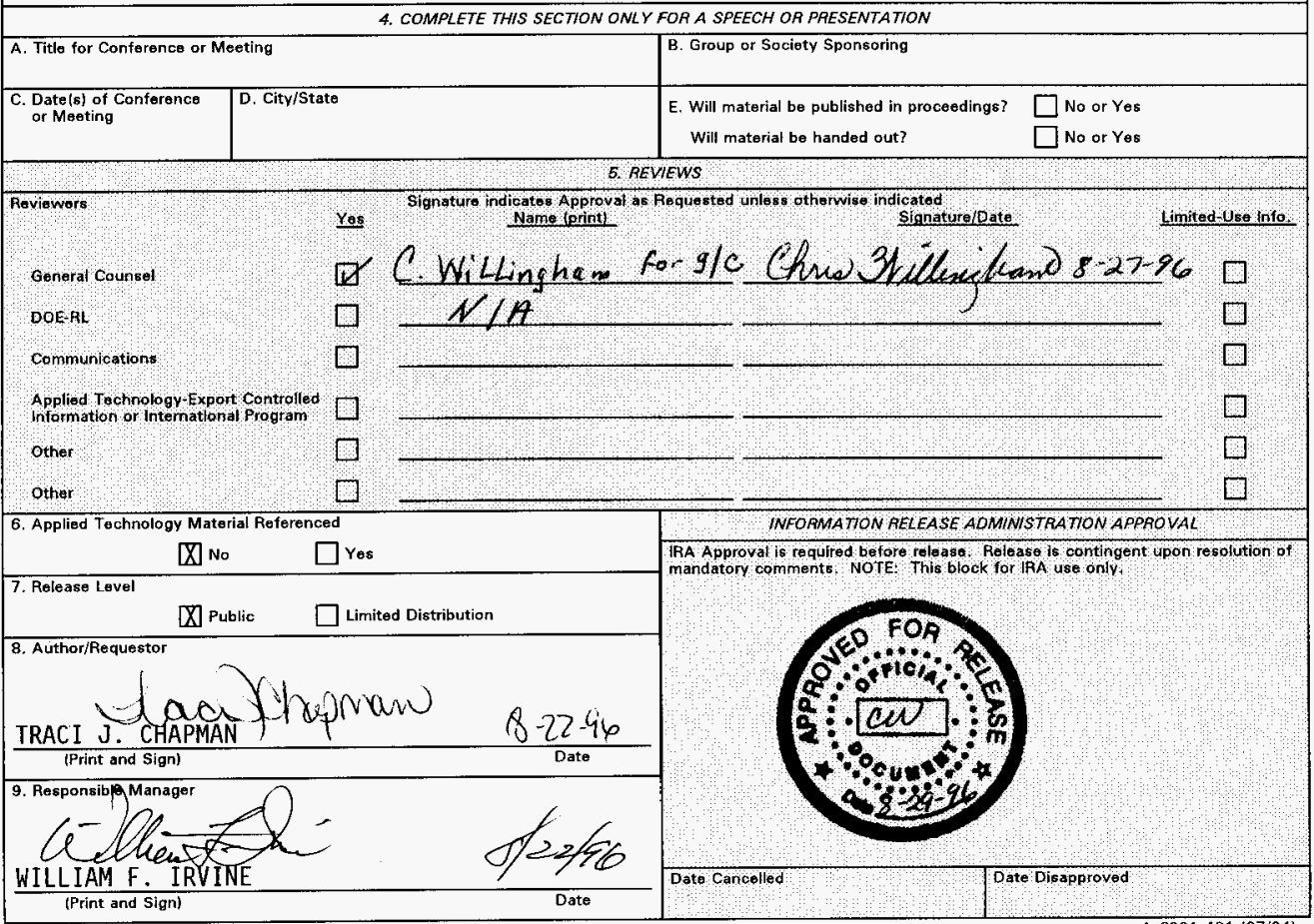


WHC-SP-1187, Rew 0

Document iD Humber:

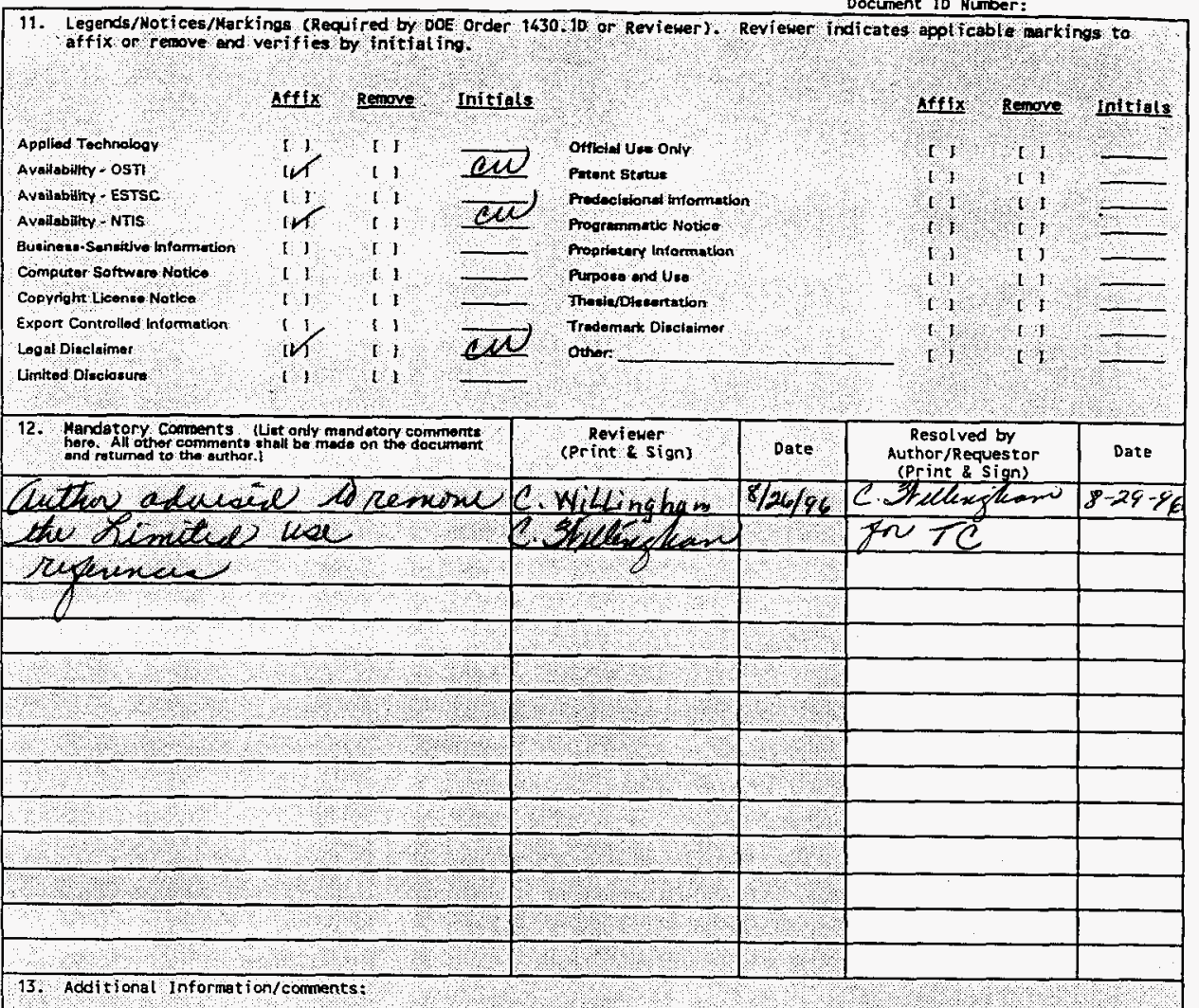




\section{TRANSPORTATION \& PACKAGING HQ SUPPORT WBS 8.1.2/8.1.3}

FY 1997 Work Plan

WHC-SP-1187 Rev. 0

\subsection{TECHNICAL SECTION}

\subsection{Project Mission}

To develop and implement baseline and state-of-the-art transportation and packaging resources for $\mathrm{DOE}$, and its support contractors. These resources include effective strategies, tools and techniques, packaging and transportation systems, operational methods, policy and guidance focused at providing safe, efficient, regulatory compliant and cost-effective materials transportation. Upon request, and with DOE approval these same services can be provided to other agencies and contractors; e.g., DOT, GSA.

Staffing to provide these baseline transportation and packaging resources is supplemented by outsourcing to specialized subcontractors.

Transportation Training establishes the nationwide baseline transportation training program to comply with existing regulations, which will allow hazardous material (HazMat) employees, DOE and contractor HazMat shippers to meet their job requirements. It will also provide training to develop a career path for employees to ensure a highly trained and skilled work force is available to meet the U.S. Department of Energy (DOE) transportation needs.

Transportation Automation provides the information technology infrastructure that will support the DOE across all programmatic areas of transportation management. This entails managing the development, upgrade, implementation, and operation of various computer codes, analytical tools, databases, and communication systems, including independent validation and verification to support both operational and research requirements.

Regulatory Compliance and Technical Assessment provides oversight and assistance to ensure that transportation and packaging operations are conducted safely and within all required laws, regulations, and orders at all DOE sites.

Explosives Classification and Program Management provides the foundation for DOE's explosives transportation activities. The efficient management of the explosives classification and transportation program throughout the DOE ensures safe, effective operations; comprehensive explosives data management; and compliance with established industrial standards and all applicable federal regulations. 


\section{TRANSPORTATION \& PACKAGING HO SUPPORT}

WBS 8.1.2/8.1.3

FY 1997 Work Plan

HHC-SP-1187 Rev. 0

Packaging Engineering and Analysis is an integrated program based on an overall assessment of Departmental transportation packaging needs. An integrated Departmental packaging development program involves utilization of Departmental resources in the most efficient and cost-effective manner. Packagings that can serve the needs of multiple programs and sites will be developed where appropriate; packaging development for specific programs will be supported where appropriate funding is available. Consideration will be given to the use of recycled materials in the development of packagings. Testing and evaluation will be performed as needed to support packaging development and certification.

\subsection{Project Technical Endpoint Targets}

The DOE overall strategic mission has changed. Emphasis has shifted from defense programs support to environmental restoration, with many new transportation applications. The packaging and transportation of DOE materials, including hazardous materials, hazardous substances and hazardous and mixed wastes, is a continually identified stakeholder concern and issue. The Department must be prepared to assure full regulatory compliance, actively consider and interact regarding stakeholder views/concerns, and implement a comprehensive and coordinated transportation program.

Performance Packaging provides package testing capabilities to address DOT-7A performance requirements for radioactive materials and wastes, and testing to meet UN performance standards for hazardous materials and wastes as specified under the DOT Hazardous Materials Regulations. Criteria are established to assess package-vendor capabilities to test, evaluate and document performance packages against national and international standards.

Packaging Safety Assessment provides review and confirmatory analysis of Safety Analysis Reports for Packaging (SARPs), risk assessment and NEPA documentation developed within the DOE EM and DP programs and by other federai agencies and contractors. Assessments are performed against applicable regulations and standards.

All of the strategies described above are provided to federal agencies and their contractors at facility locations where economy of scale makes individual staffing of site resources containing the prerequisite expertise nonfeasible for economic reasons and where resources at Hanford can be leveraged effectively to meet the needs of smaller site operations.

Transportation \& Packaging (T\&P) will work closely with the package users to obtain the necessary package design requirements and payload technical information. T\&P will coordinate with DOE, Lawrence Livermore National 


\section{TRANSPORTATION \& PACKAGING HO SUPPORT}

WBS 8.1.2/8.1.3

FY 1997 Work Plan

WHC-SP-1187 Rev, 0

Laboratory, and other regulatory agencies to expedite the regulatory package review and keep these organizations informed on current package designs and any proposed changes that may affect the regulatory hardware and certification of the package to assure the delivery of an approved shipping package.

\subsection{Summary-Level Forecasting Data}

To accomplish T\&P's mission to develop and implement baseline and state of the art transportation and packaging resources for DOE, and other federal agencies as well as their support contractors the program must meet specific objectives in each of the following areas.

Transportation Logistics:

- to ensure qualified motor carriers are available to transport hazardous wastes, substances and radioactive materials and special shipping campaigns for DOE and its contractors.

- to ensure motor carrier evaluation program plan and evaluation criteria remain up to date.

- to ensure state-of-the-art tools and operational methods are available for implementation.

- To ensure the Transportation Operations Manual is available and updated as needed and distributed to DOE and site contractor traffic management personnel.

Transportation Training:

- to ensure availability of quality training programs focused on HazMat shipping, packaging, and transportation functions and applicable requirements and standards.

- to ensure transport personnel have access to mandated regulatory training.

Transportation Automation:

- to ensure integrity of data and related automated systems through strict configuration management.

- to ensure availability of automated transportation management systems that support regulatory compliance and cost-effective operations.

Regulatory Compliance:

- to ensure systems and methods are in place to conduct packaging and transportation operations in a safe and compliant manner.

- to ensure up-to-date procedures and systems are in place to achieve efficient and cost-effective operations. 


\section{TRANSPORTATION \& PACKAGING HO SUPPORT WBS 8.1.2/8.1.3}

FY 1997 Work Plan

WHC-SP-1187 Rev. 0

Explosives Classification and Program Management:

- to ensure systems are in place and utilized to classify and ship explosives materials safely.

- to ensure explosive classification activities are conducted in an efficient and cost-effective manner.

- to ensure timely distribution of explosive descriptions and classification actions.

Packaging Engineering and Analysis:

- to provide safe, compliant and cost-effective packagings and transportation systems for radioactive and/or hazardous materials and wastes.

Performance Packaging:

- to ensure DOT-7A packagings and UN performance packagings are tested and evaluated to meet national and international standards.

\subsection{Drivers}

Federal and State regulations including DOE Orders.

\subsection{Project Requirements}

Transportation Logistics ensures transportation activities are performed in compliance with applicable laws, regulations, and DOE Orders. Specific areas in Transportation Logistics include assessments associated with operational policy analysis and development, productivity and safety enhancements through improved operations technology and methods, and the development and implementation of operational systems. Operations technology and methods include operational analysis (e.g., freight rate negotiations, motor carrier evaluation program, and the Transportation Operations Manual).

Transportation Training supports the regulatory requirements for training of transportation personnel. This program provides training courses nationwide to DOE and its contractor personnel, federal agency personnel, state, Tribal and local officials, commercial carrier employees, and others on the regulatory and DOE transportation requirements. This helps to ensure that contractor packaging and transportation of DOE materials, including radioactive materials, hazardous substances, and hazardous and mixed wastes, are performed consistently and in compliance with applicable laws, regulations, and DOE Orders.

Transportation Automation consists of developing and implementing throughout the DOE complex operational systems that apply various computer codes, models, 


\section{TRANSPORTATION \& PACKAGING HQ SUPPORT \\ WBS 8.1.2/8.1.3}

FY 1997 Work Plan

WHC-SP-1187 Rev. 0

and databases to improve efficiency, cost-effectiveness, and safety of DOE Traffic Management activities. These systems are used to manage overal1 DOE transportation operations, and are invaluable in responding to internal DOE and external inquiries.

Regulatory Compliance and Technical Assessment provides review and analysis to respond to regulatory changes and address high-visibility issues that affect DOE transportation management. Assessment teams are provided to evaluate field element and contractor transportation activities and to provide technical assistance.

Explosives Classification and Program Management consists of classification reviews, explosives site assessments, information management, reclassification of previous1y DOT-registered explosives under HM-181, maintenance of the Explosives Classification and Shipment Program Management P1an, and other related explosives classification and transportation activities.

Packaging Engineering and Analysis involves engineering, design, analysis, and testing for packaging development. DOE-HQ will provide guidance to Department elements for packaging systems development.

\subsection{Project Issues and Assumptions}

The regulatory environment will continue to change and apply even stricter standards to the packaging and transportation of hazardous materials.

Compliance to applicable national and international consensus standards and regulatory guides will continue to be mandatory for federal agencies and their contractors.

The annual budgets used by federal agencies and their contractors for packaging and transportation system development will shrink considerably. Privatization initiatives by federal agencies and government contractors will place more work in the private sector.

T\&P will actively pursue work within the federal sector where economies can be achieved by leveraging existing transportation and packaging resources at Hanford.

The DOT-7A testing program will continue at current levels of activity. 


\section{TRANSPORTATION \& PACKAGING HO SUPPORT}

WBS 8.1.2/8.1.3

FY 1997 Work Plan

WHC-SP-1187 Rev. 0

\subsection{Work Breakdown Structure}

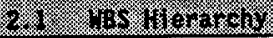

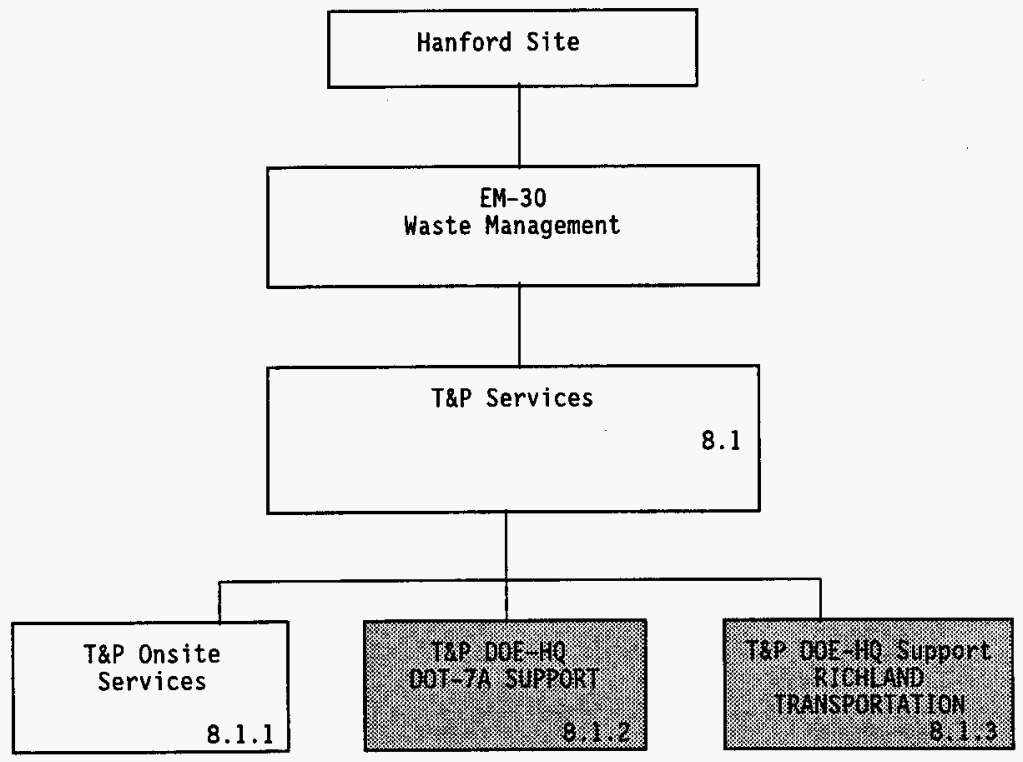




\section{TRANSPORTATION \& PACKAGING HO SUPPORT WBS 8.1.2/8.1.3}

FY 1997 Work Plan

WHC-SP-1187 Rev. 0

\subsection{WBS Dictionary}

\begin{tabular}{|c|c|c|}
\hline $\begin{array}{l}1 \text { PROJECT TITLE/PARTICIPANT } \\
\text { Transportation Packaging }\end{array}$ & $\begin{array}{l}2 \text { DATE } \\
\text { August } 1996\end{array}$ & 3 DOE-HQ UBS CCOE: \\
\hline $\begin{array}{l}4 \text { DOE-RL WBS ELEMENT COOE } \\
8.1 .2 / 8.1 .3\end{array}$ & $\begin{array}{l}5 \text { WBS ELEMENT TITLE } \\
\text { TRP DOE-HO SUPport }\end{array}$ & \\
\hline 6 CONTRACTOR MBS ELEMENT COOE: & 7 REVISION \# AND AUTHORIZATION & 8 DATE \\
\hline \multicolumn{3}{|l|}{9 APPROVED CHANGES } \\
\hline 10 SYSTEM DESIGN DESCRIPIION & $\begin{array}{l}11 \text { BUDGET AND REPORTING NUMBER } \\
\text { EW5010, EW5020 and HA0120 }\end{array}$ & \\
\hline
\end{tabular}

\section{ELEMENT TASK DESCRIPTION}

Ensures transportation activities are performed in accordance with applicable laws, regulations, and DOE Orders. Transportation Automation consists of operational systems and databases, that include development and implementation of various computer codes to improve efficiency, cost effectiveness, and safety.

Provides review and analysis to respond to regulatory changes and addresses high-visibility issues that affect transportation management. The Training Programs provide HazMat and operational training courses nationwide to DOE and its contractors, federal agency personnel, state and local officials, carriers, and others on the regulatory and DOE requirements.

Provides new explosives classifications, explosives site assessments, information management, and reclassification of previously DOT registered explosives. Packaging engineering provides design, analysis and testing for packaging development. Packaging Operations supports the EM-76 effort in evaluating the transportation and packaging needs across the DOE complex. 


\section{TRANSPORTATION \& PACKAGING HO SUPPORT}

WBS 8.1.2/8.1.3

FY 1997 Nork Plan

WHC-SP-1187 Rev. 0

Provides engineering, testing and project/program management services to the U.S. Department of Energy, Transportation, Emergency Management and Analytical Services. Services provided are Type A radioactive materials packaging testing and evaluation. 


\section{TRANSPORTATION \& PACKAGING HO SUPPORT WBS 8.1.2/8.1.3}

FY 1997 Work PIan

WHC-SP-1187 Rev. 0

\subsection{WBS Responsibility Assignment Matrix}

\begin{tabular}{|c|c|c|c|c|c|}
\hline $\begin{array}{l}\text { PROGRAM } \\
\text { ELEMENT }\end{array}$ & ACTIVITY & COST ACCOUNT & TITLE & $\begin{array}{c}\text { RESPONSIBLE } \\
\text { MANAGER }\end{array}$ & $\begin{array}{l}\text { RESPONSIBLE } \\
\text { ORGANIZATION } \\
\end{array}$ \\
\hline 8.1 .2 & DOT-7A Testing & IYHXO1 & $\begin{array}{l}\text { DOT-7A Testing } \\
\text { Program }\end{array}$ & D. L. McCalt & 84400 \\
\hline 8.1 .3 & Logistics & IYHAAT & $\begin{array}{l}\text { Transportation } \\
\text { Logistics }\end{array}$ & J. H. Portsmouth & 84600 \\
\hline 8.1.3 & Automation & IYHAB 1 & $\begin{array}{l}\text { Trensportation } \\
\text { Autongtion }\end{array}$ & J. H. Portsmouth & 84600 \\
\hline 8.1 .3 & $\begin{array}{l}\text { Regulatory } \\
\text { Compl iance }\end{array}$ & IYHAC1 & $\begin{array}{l}\text { Regulatory } \\
\text { Compl iance \& } \\
\text { Technical } \\
\text { Assessments } \\
\end{array}$ & $\begin{array}{l}\text { J. H. Portsmouth } \\
\text { D. L. McCall }\end{array}$ & $\begin{array}{l}84600 \\
84400\end{array}$ \\
\hline 8.1 .3 & $\begin{array}{l}\text { Program } \\
\text { Managenent }\end{array}$ & 1YHAD 1 & $\begin{array}{l}\text { Program } \\
\text { Management }\end{array}$ & $\begin{array}{l}\text { J. H. Portsmouth } \\
\text { D. L. McCall }\end{array}$ & $\begin{array}{l}84600 \\
84400 \\
\end{array}$ \\
\hline 8.1 .3 & Explosives & 1YHBA1 & $\begin{array}{l}\text { Explosives } \\
\text { Classification \& } \\
\text { Review }\end{array}$ & D. L. MeCall & 84400 \\
\hline 8.1 .3 & $\begin{array}{l}\text { Packaging } \\
\text { Operations }\end{array}$ & 1YнBB 1 & $\begin{array}{l}\text { Packaging } \\
\text { Operations }\end{array}$ & D. L. McCall & 84600 \\
\hline 8.1 .3 & Training & IYHAE1 & Training & J. H. Portsmouth & 84600 \\
\hline
\end{tabular}




\section{TRANSPORTATION \& PACKAGING HQ SUPPORT \\ WBS 8.1.2/8.1.3}

FY 1997 Work Plan

WHC-SP-1187 Rev. 0

\subsection{SCHEDULE BASELINE}

\subsection{Program Master Basel ine Schedule}

The workscope described in detail in Section 1.0 of this offsite MYWP and which is generally described as Transportation Logistics, Transportation Training, Transportation Automation, Regulatory Compliance, Packaging Engineering and Analysis, Explosives Classification, Performance Packaging, and Packaging Safety Assessment, is governed by the following technical standards and regulations:

49 CFR 171.2(a); 171.11; 171.12; 176.11; and generally 49 CFR 107-180 DOE Orders 1540.1, 6(f); 5700.6C, 9(a); 1000.3C; DOE Order 461 Series.

The T\&P organization does not use the $P / X$ Scheduling system for the work done in the organization. 


\subsection{Milestone List}

\begin{tabular}{|c|c|c|c|}
\hline \multirow{3}{*}{$\begin{array}{c}\text { Milestone } \\
\text { Type }\end{array}$} & & MILESTOME L IST & \\
\hline & $\begin{array}{l}\text { Control } \\
\text { Number }\end{array}$ & Milestone Description & $\begin{array}{l}\text { Milestone } \\
\text { Completion Date } \\
\end{array}$ \\
\hline & & $\begin{array}{l}\text { Currently there are no FY } 1997 \text { milestones. When mi lestones are } \\
\text { negotiated between DOE-HQ and Transportation \& Packaging/RL, they can } \\
\text { be found under ADS } 2601 \text { titled 'Richland Transportation' in the } \\
\text { Progress Tracking System. }\end{array}$ & \\
\hline
\end{tabular}

- TPA, HQ, RL, and selected contractor milestones

- On Tri-Party Agreenent Milestones, also designate if they are HO, RL

\subsection{Milestone Description Sheets}

N/A 
WHC-SP-1187 Rev. 0

4.0 Cost Basellne

4.1

\section{BUDGET AUTHORITY SUMMARY BY YEAR BY ADS}

(\$000s)

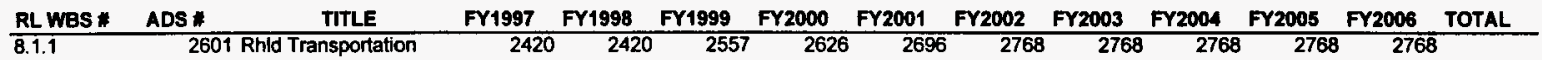


4.1

\section{BUDGET AUTHORITY BY YEAR BY ADS}

(\$000s)

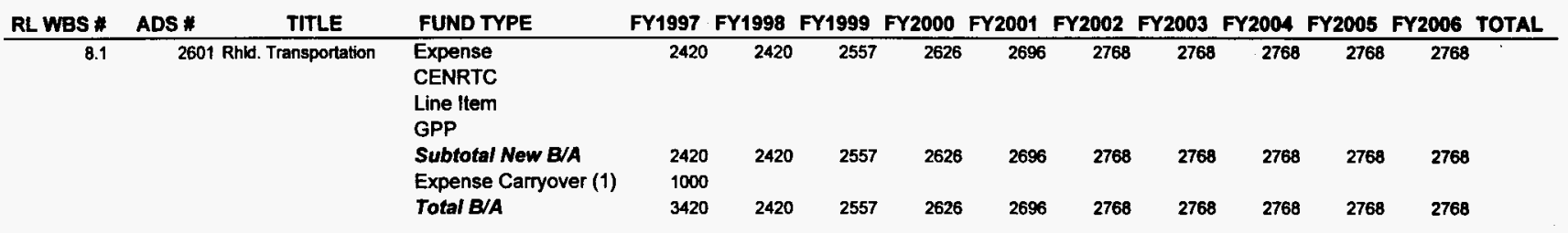

\begin{tabular}{|c|c|c|c|c|c|c|c|c|c|c|}
\hline PROGRAM NEW BIA & 2420 & 2420 & 2557 & 2626 & 2696 & 2768 & 2768 & 2768 & 2768 & 2768 \\
\hline PROGRAM EXPENSE CARRYOVER & 1000 & & & & & & & & & \\
\hline PROGRAM TOTAL BIÁ & 3420 & 2420 & 2557 & 2626 & 2696 & 2768 & 2768 & 2768 & 2768 & 2768 \\
\hline
\end{tabular}

(1) Includes Only Expense Carryover Approved By Site Management Board (SMB) Prior To 10/1/96. 
4.1

\section{COST BASELINE BY YEAR BY ADS}

(\$000s)

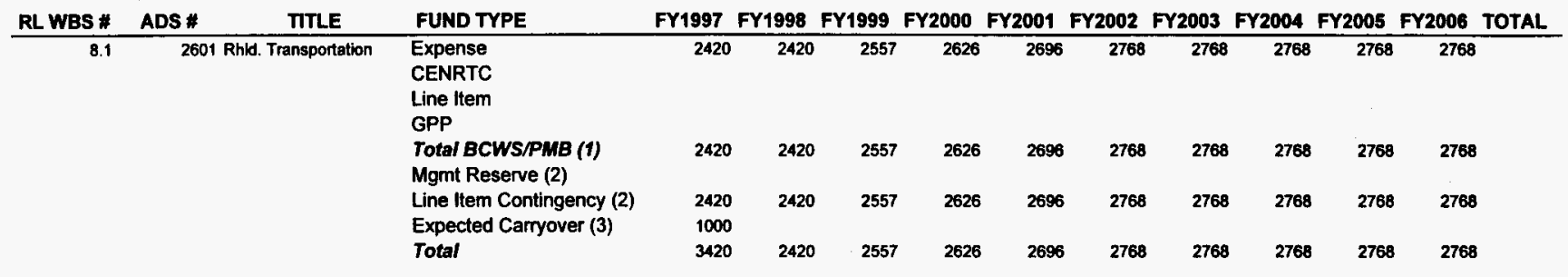

\begin{tabular}{|c|c|c|c|c|c|c|c|c|c|c|}
\hline PROGRAM BCWS/PMB & 3420 & 2420 & 2557 & 2626 & 2696 & 2768 & 2768 & 2768 & 2768 & 2768 \\
\hline PROGRAM TOTALL & 3420 & 2420 & 2557 & 2626 & 2696 & 2768 & 2768 & 2768 & 2768 & 2768 \\
\hline
\end{tabular}

\footnotetext{
(1) Budgeted Cost Of Work Scheduled (BCWS) Equals Performance Measurement Baseline (PMB).

(2) Management Reserve And Line Item Contingency Held By RL.

(3) Includes Expected Expense Carnyover Requested By Formal Change Control In FY1997.
} 


\subsection{Basis of Estimate}

\begin{tabular}{|c|c|c|c|c|}
\hline WBS Element/Cost Category & & FY 1997 & FY 1998 & FY 1999 \\
\hline \multirow{2}{*}{$\begin{array}{l}\text { WBS } 8.1 .2 / 8.1 .3 \\
\text { T\&P DOE-HQ Support }\end{array}$} & $\$$ & $2.42 M$ & $2.49 \mathrm{M}$ & $2.557 \mathrm{M}$ \\
\hline & FTE & 13.0 & 13.7 & 13.7 \\
\hline \multicolumn{5}{|c|}{$\begin{array}{l}\text { Cost detail will be tracked by B\&R code in the Progress Tracking System. } \\
\text { The funding for the DOT-7A Testing Program was inadvertently omitted in the ADS guidance for FY } 1997 \\
\text { The activity is included in the ADS } 2601 \text {, the funding will come in under a different mechanism. The } \\
\text { funding for the DOT-7A Testing Program will be \$250K. }\end{array}$} \\
\hline
\end{tabular}


Exhibit: Program Average FTE Projections by COCS Categories Program WBS/Title: ADS 2601 Richland Transportation

\begin{tabular}{|c|c|c|c|c|c|c|c|c|c|c|c|}
\hline $\operatorname{cocs}$ & Title & FY 1997 & FY 1998 & FY 1999 & FY 2000 & FY 2001 & FY 2002 & FY 2003 & FY2004 & FY 2005 & FY 2006 \\
\hline C000 & Crafts & & & & & & & & & & \\
\hline $\mathrm{C010}$ & Carpenters & & & & & & & & & & \\
\hline C020 & Electricians & & & & & & & & & & \\
\hline C030 & Heating Air-Conditioning and Refrig Mechanics (HVAC) & & & & & & & & & & \\
\hline C040 & Machinists & & & & & & & & & & \\
\hline $\cos 0$ & Masons & & & & & & & & & & \\
\hline C060 & Milwrights & & & & & & & & & & \\
\hline $\mathrm{co70}$ & Painters & & & & & & & & & & \\
\hline Co80 & Plumbers and Pipefitters & & & & & & & & & & \\
\hline $\operatorname{coso}$ & Structural and Metal Workers & & & & & & & & & & \\
\hline C100 & Vehicle and Mobile Equipment Mechanics & & & & & & & & & & \\
\hline C110 & Welders & & & & & & & & & & \\
\hline C120 & Other Crafts & & & & & & & & & & \\
\hline E000 & Engineers & 2.2 & 2.3 & & & & & & & & है \\
\hline E010 & Chemical Engineers & & & & & & & & & & \\
\hline E020 & Civil Engineers & & & & & & & & & & \\
\hline E040 & Electrical Engineers & & & & & & & & & & \\
\hline E050 & Environmental Engineers & 0.5 & 0.5 & & & & & & & & \\
\hline E060 & Industrial Engineers & & & & & & & & & & \\
\hline E070 & Mechanical Engineers & 1 & 1 & & & & & & & & \\
\hline E080 & Nuclear Engineers & $\ldots$ & & & & & & & & & \\
\hline E090 & Petroleum/Mining Engineers & & & & & & & & & & \\
\hline E100 & Plant Engineers & 0.7 & 0.8 & & & & & & & & \\
\hline E110 & Quality Assurance/Control Engineers & & & & & & & & & & \\
\hline E120 & Safety Engineers & & & & & & & & & & \\
\hline E130 & Other Engineers & & & & & & & & & & \\
\hline E140 & Construction Engineers & & & & & & & & & & \\
\hline
\end{tabular}


Exhibit: Program Average FTE Projections by CoCS Categories

Program WBS/Title: ADS 2601 Richland Transportation

\begin{tabular}{|c|c|c|c|c|c|c|c|c|c|c|c|}
\hline COCS & Title & FY 1997 & FY 1998 & FY 1999 & FY 2000 & FY 2001 & FY 2002 & FY 2003 & FY 2004 & FY 2005 & FY 2006 \\
\hline G000 & General Admin, Secretarial \& Clerical Support & 3.0 & 3.5 & & & & & & & & \\
\hline G010 & Administrative Assistants & 0.3 & 0.5 & & & & & & & & \\
\hline G020 & Office Clerks (General) & 1.9 & 2.1 & & & & & & & & \\
\hline G030 & Office Clerks (Specialized) & & & & & & & & & & \\
\hline G040 & Secretaries & 0.8 & 0.9 & & & & & & & & \\
\hline G050 & Typist and Word Processors & & & & & & & & & & \\
\hline G060 & Other General Admin, Secretarial and Clerical Support & & & & & & & & & & \\
\hline LOOO & Laborers and General Service Workers & 0.0 & 0.0 & & & & & & & & \\
\hline L010 & Firefighters & & & & & & & & & & \\
\hline L020 & Food Service Workers & & & & & & & & & & \\
\hline Lo30 & Janitors and Cleaners & & & & & & & & & & \\
\hline LO40 & Laundry Workers & & & & & & & & & & \\
\hline L050 & Handlers, Helpers and Laborers (General) & & & & & & & & & & \\
\hline L060 & Handlers, Helpers and Laborers (Specialized) & & & & & & & & & & \\
\hline LO70 & Light Vehicle Drivers & & & & & & & & & & \\
\hline Lo80 & Security Guards & & & & & & & & & & \\
\hline Lo90 & Other Laborers and General Services Workers & & & & & & & & & & \\
\hline MOOD & Gen Mgrs, Exec, 1st Line Suprv'sr \& Prog/Proj Mgrs & 1.1 & 1.2 & & & & & & & & \\
\hline M010 & First Line Supervisors & & & & & & & & & & \\
\hline M020 & General Managers and Executives & 1.1 & 1.2 & & & & & & & & \\
\hline M030 & Project and Program Managers & & & & & & & & & & \\
\hline M040 & Other Managers & & & & & & & & & & \\
\hline
\end{tabular}




\section{Exhibit: Program Average FTE Projections by COCS Categories}

\section{Program WBS/Title: ADS 2601 Richland Transportation}

\begin{tabular}{|c|c|c|c|c|c|c|c|c|c|c|c|}
\hline COCS & Tille & FY 1997 & FY 1998 & FY 1999 & FY 2000 & FY 2001 & FY2002 & FY 2003 & FY 2004 & FY 2005 & FY 2006 \\
\hline$\overline{P 000}$ & Professional Administrative \& Related Occupations & 6.7 & 6.7 & & & & & & & & \\
\hline P010 & Accountants and Auditors & & & & & & & & & & \\
\hline P020 & Architects & & & & & & & & & & \\
\hline P030 & Buyers, Procurement and Contracting Specialists & & & & & & & & & & \\
\hline P040 & Communications Specialists & & & & & & & & & & \\
\hline P050 & Compliance Inspectors & & & & & & & & & & \\
\hline P060 & Computer Systems Analysts & & & & & & & & & & \\
\hline P070 & Cost Estimators and Planners and Schedulers & & & & & & & & & & \\
\hline P080 & Health Physicists & & & & & & & & & & \\
\hline P090 & Industrial Hygienists & & & & & & & & & & \\
\hline P100 & Lawyers & & & & & & & & & & \\
\hline P110 & Personnel and Labor Relations Specialists & & & & & & & & & & \\
\hline P120 & Physicians & & & & . & & & & & & \\
\hline P130 & Physician Assist, Nurses \& Oth Medical Supt Occup'tns & & & & & & & & & & \\
\hline P140 & Safeguards and Other Security Specialists & & & & & & & & & & \\
\hline P150 & Trainers & & & & & & & & & & \\
\hline $\begin{array}{l}\text { P160 } \\
\text { P170 }\end{array}$ & $\begin{array}{l}\text { Technical Writers, and Editors } \\
\text { Other Administrative \& Professional Other Occupations }\end{array}$ & 6.7 & 6.7 & & & & & & & & \\
\hline Roo0 & Operators & 0.0 & 0.00 & & & & & & & & \\
\hline R010 & Chemical System Operators & & & & & & & & & & \\
\hline R020 & Drillers & & & & & & & & & & \\
\hline R030 & Material Moving Equipment Operators & & & & & & & & & & \\
\hline R040 & Nuclear Plant Operators & & & & & & & & & & \\
\hline R050 & Nuclear Waste Process Operators & & & & & & & & & & \\
\hline R060 & Production Systems Operators & & & & & & & & & & \\
\hline R070 & Utilities Operators & & & & & & & & & & \\
\hline R080 & Other Operators & & & & & & & & & & \\
\hline
\end{tabular}




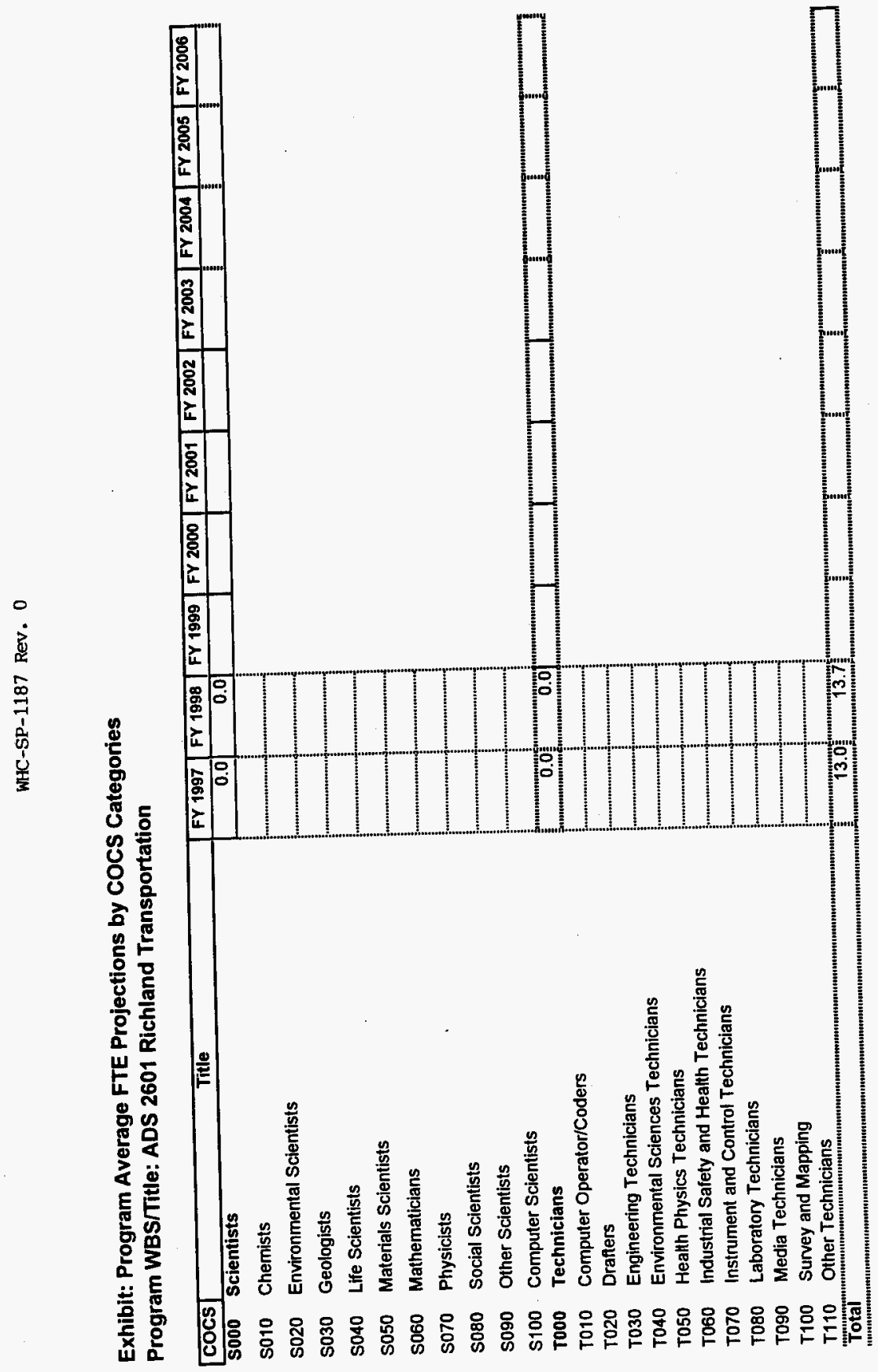




\section{TRANSPORTATION \& PACKAGING HQ SUPPORT \\ WBS 8.1.2/8.1.3}

FY 1997 Work Plan

WHC-SP-1187 Rev. 0

Funding Estimates for FY 1997 are based on funding guidance received from DOEHQ, Transportation, Emergency Management and Analytical Services.

Past and current year projected expenditures

FY 1994 (\$7.5M) FY 1995 (\$6.3M) FY 1996 (\$3.4M) FY 1997 (\$2.42M)

The number of major projects/tasks initiated in previous years

FY 1994 (EM - 28 major projects/tasks)

(EH - 5 Dockets opened)

(Work for other sites - Approx. \$60K)

FY 1995 (EM - 24 Major projects/tasks)

(EH - 4 Dockets opened)

(Work for other sites - \$80K)

FY 1996 (EM - 30 Major projects/tasks)

(EH - 0 Dockets Opened)

(Work for Other sites \$120K)

Projects currently scheduled and projected for FY 1997

FY 1997 Est (EM/EH - 8 major projects/tasks, \$2.6M FY 1996 Carryover \$IM)

(DP - SARP reviews, \$250K)

(Work for Other sites - \$200K)

(RTG - \$361K)

Basis of this estimate includes projects currently scheduled for FY 1997 and the percentage of walk-in work that is typical after the start of the fiscal year. Walk-in work that comes in after the fiscal year starts generally increases each year's workscope and budget by 20 percent. Budget for FY 1997 is $\$ 2.42 \mathrm{M}$.

Packaging needs identified in the offsite needs assessment effort:

Type B Drum Overpack

Family of metal boxes

New or updated metal drum and box specifications

New systems contract for procurement of drums

Replacement casks for B-3 and $\mathrm{FL}-10$

Shielded version of Type B Drum Overpack

TRIGA fuel cask 


\section{TRANSPORTATION \& PACKAGING HQ SUPPORT \\ WBS 8.1.2/8.1.3}

FY 1997 Work Plan

WHC-SP-1187 Rev. 0

The number of engineering and logistical studies from past years:

FY 1994 - 5 engineering studies, 3 logistical studies

FY 1995 - 3 engineering studies, 2 logistical studies

FY 1996 - 0 engineering studies, 0 logistical studies

Projected engineering and logistical studies for FY 1997

FY 1997 Projected - 1 engineering study, 1 logistical study

Based on previous year activity, scheduled work and expected walk-in work.

Regulatory changes requiring manual and procedural changes

Implementation of Drug and Alcohol testing standards for drivers

Changes in DOE Orders 5480.3 and DOE Order 1540 Series to 460 Series.

FY 1996 and FY 1997 implementation of HM-169A rule changes.

Implementation of HM-215 rule-making which changes the classification and description of certain materiats and hazard communication requirements.

The number of classes held and students trained in past and present year and projections for FY 1997:

Fy 1994 ( 55 Classes, 1100 students)

Note: Attendance in FY 1994 reflects mandatory federal training requirements from rule-making $\mathrm{HM}-126 \mathrm{~F}$.

FY 1995 (48 Classes, $1000+$ students)

FY 1996 ( 33 Classes, 1000+ students)

Projected for FY 1997 ( 35 Classes, 1000+ students)

Based on past and present levels of activity as described above, FY 1997 projected workscope will require 13 FTEs. It is also assumed that some portion of this work will be outsourced locally and nationally to obtain engineering and other technical services needed to meet milestones committed to by T\&P management and staff.

Management and Administration will require 3.2 FTEs.

Transportation Logistics will require .5 FTE.

Transportation Training will require 5 FTEs.

Transportation Automation will require 1.2 FTES. 


\section{TRANSPORTATION \& PACKAGING HO SUPPORT}

WBS 8.1.2/8.1.3

FY 1997 Work Plan

WHC-SP-1187 Rev. O

Explosives Classification will require 1.9 FTEs.

Performance Packaging will require 1.2 FTEs.

Total 13 FTEs for the Transportation Management and DOT-7A Testing support scope of work. 


\subsection{EXECUTION YEAR}

\subsection{Performance Measure/Objectives}

ES\&H Performance Indicator - Measures track for evaluation all first aid, recordable and lost workday injuries and lost/restricted time. The lost workday incident rate is computed per 200,000 work hours and compared to the company goal.

Schedule Performance Indicators - Measurements track and trend schedule performance on customer milestones and commitments as agreed to in project and task work plans. Schedule status and milestones are adjusted when necessary to re-baseline and to account for circumstances beyond the control of T\&P. Each major project or task is assigned internal and external milestones, and deliverables are agreed to by the customer/program and T\&P management and staff assigned to the task. Progress is reported in weekly project reports, the DOE Progress Tracking System report and by other customer requested means.

Cost Performance Indicator - Measurements track and trend cost variance on major projects and tasks. Adjustments are made if necessary for customer directed changes in work scope, budget adjustments, and other circumstances beyond the control of T\&P.

Customer Satisfaction Performance Indicator - Timely closeout of Customer Contact Records and internal and external customer surveys are conducted to assess customer satisfaction and to identify opportunities to improve the product and service quality.

To accomplish the DOE's national Transportation Management mission, the program encompasses the oversight and management of:

Transportation operations logistics for a 11 DOE non-weapons material including hazardous materials, excluding the Office of Civilian Radioactive Waste Management commercial irradiated nuclear fuel.

Packaging selection, utilization and maintenance, onsite and offsite.

Development of needed systems and technologies (i.e., packaging development, automation initiatives, and training and professional development programs).

Development and implementation of a technical assessment/technical assistance program to ensure that safe, economical, and efficient transportation services meet regulatory requirements and are consistently available to DOE programs to fulfill their missions. 


\section{TRANSPORTATION \& PACKAGING HO SUPPORT}

WBS 8.1.2/8.1.3

FY 1997 Work Plan

WHC-SP-1187 Rev. O

Transportation management supports DOE-wide activities with research and development capabilities. In that regard, T\&P is supporting DOE-HQ in developing a nation-wide transportation system information and communications infrastructure that collects, stores, and disseminates reliable transportation information throughout DOE and to other federal agencies and jurisdictions.

\subsection{Program Performance Baseline Schedule}

Not Applicable 
5.3

\section{COST BASELINE FOR EXECUTION YEAR BY PROGRAM BY FUND TYPE BY MONTH}

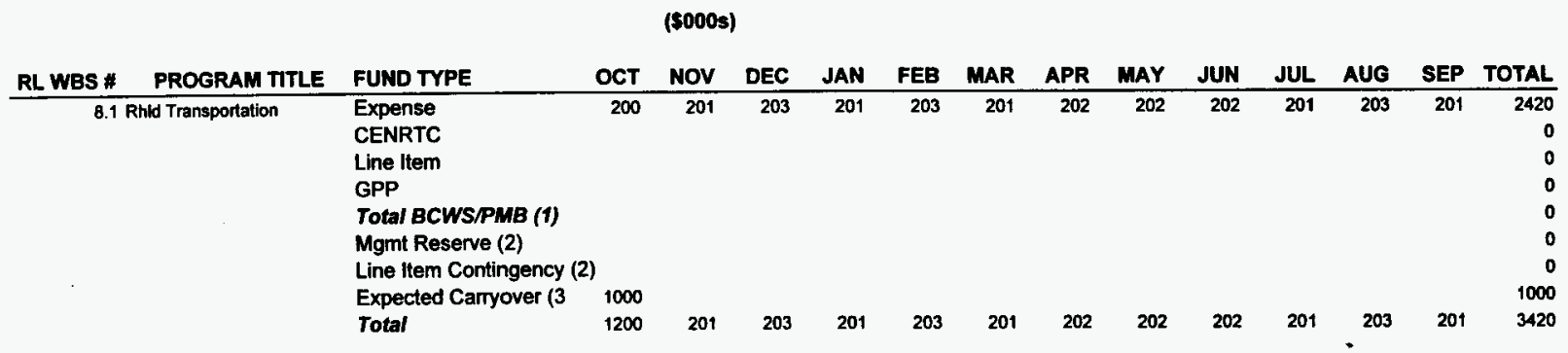

\begin{tabular}{|c|c|c|c|c|c|c|c|c|c|c|c|c|c|}
\hline PROGRAM BCWS/PMB & 200 & 201 & 203 & 201 & 203 & 201 & 202 & 202 & 202 & 201 & 203 & 201 & 2420 \\
\hline PROGRAM TOTAL & 1200 & 201 & 203 & 201 & 203 & 201 & 202 & 202 & 202 & 201 & 203 & 201 & 3420 \\
\hline
\end{tabular}

(1) Budgeted Cost Of Work Scheduled (BCWS) Equals Performance Measurement Baseline (PMB).

(2) Management Reserve Held By RL And Line Item Contingency Held By RL.

(3) Includes Expected Expense Carryover Requested By Formal Change Control In FY1997. 
5.4

\section{COST BASELINE FOR EXECUTION YEAR BY PROGRAM BY COST ELEMENT BY MONTH}

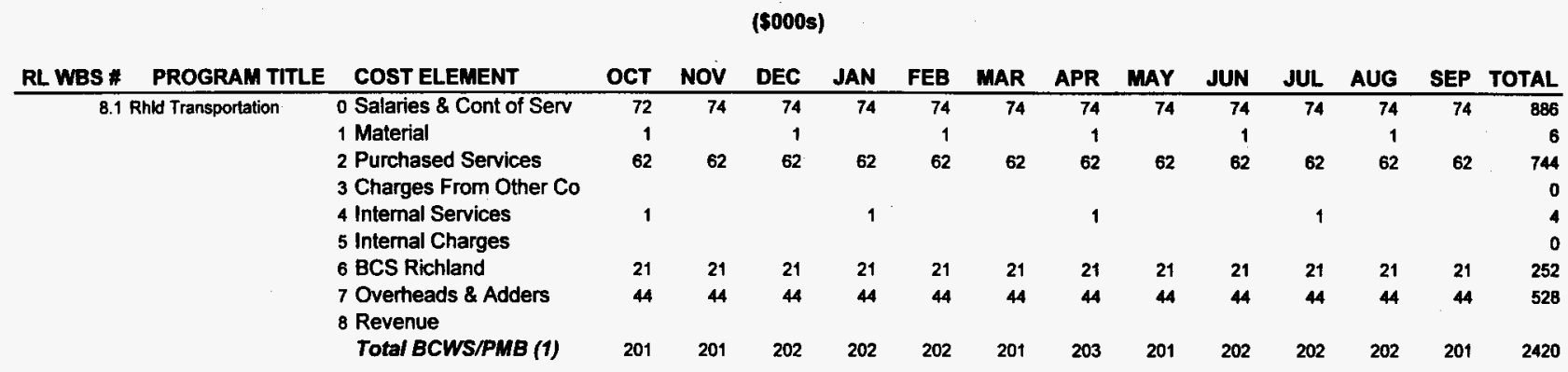

201

201

$202 \quad 202$

$202 \quad 201 \quad 203$

201

202

202

202

201




\section{TRANSPORTATION \& PACKAGING HO SUPPORT}

WBS 8.1.2/8.1.3

FY 1997 Work Plan

WHC-SP-1187 Rev. 0

\subsection{Program Funding Required}

The Transportation Operations program funding for FY 1997 will be \$2.42M, with an additional SIM in carryover from FY 1996 as identified by DOE-HQ EM-76.

The DOT-7A Testing program funding for FY 1997 will be a budget of \$250K; however, the funding is not included in the ADS guidance and will come in under another mechanism. Subsequent year funding is estimated to remain level due to standardization of packagings across the DOE complex necessitating fewer tests to meet DOT-7A standards.

\subsection{References}

N/A 


\section{TRANSPORTATION \& PACKAGING HO SUPPORT Radioisotope Thermoelectric Generator (WBS 5.1.3) and Defense Programs}

FY 1997 Work Plan

WHC-SP-1187

\subsection{TECHNICAL SECTION}

\subsection{Project Mission}

\section{Radjoisotope Thermoelectric Generator}

This work breakdown structure element encompasses the activities conducted at Hanford in support of DOE Office of Space and Defense Power Systems in the development of the Radioisotope Thermoelectric Generator (RTG) Transportation System (RTGTS). The goal of this effort is to develop a transportation system for the transport of RTGs in full compliance with the requirements of the U.S. Department of Transportation (DOT), the U.S. Nuclear Regulatory Commission (NRC), DOE guidance, and approved RTG User Community functional requirements and guidance.

\section{Defense Programs}

T\&P has been requested by the DOE-Albuquerque (DOE-AL) Field Office Nuclear Explosives Safety Division (NESD) to participate as a member of the Transportation Safety Review Panel (TSRP). The TSRP has the responsibility for reviewing Safety Analysis Reports for Packaging (SARPs) and Transportation Safety Risk Assessments (TSRAs), providing comments to the applicant, and developing the Safety Evaluation Reports. This work is in support of DOE Order 5610.10, for the transportation of nuclear explosive components.

\section{Work for Other Sites}

This work category provides other DOE sites with cost reimbursement Hazardous Materials (HAZMAT) training as well as operational classes, such as Federal Motor Carrier Safety Regulations and vehicle inspections classes, transportation automation expertise and assistance, freight bill processing and ATMS operation. Also provided is transportation management technical assessment and oversight assistance, as requested.

This work directly supports DOE's mission in assisting other DOE site locations with transportation management expertise and training classes that may not be available at their locations.

This work also supports the Hanford Site mission by providing work scope and additional funding to augment the Hanford Site funding levels, thereby allowing a "center of expertise" in training and automation areas to be 


\section{TRANSPORTATION \& PACKAGING HO SUPPORT Radioisotope Thermoelectric Generator (WBS 5.1.3) and Defense Programs}

FY 1997 Work Plan

WHC-SP-1187

available to serve site needs. Hanford workload alone is insufficient to retain the highly-skilled personnel in these areas.

\subsection{Project End Point Targets}

\section{Radioisotope Thermoelectric Generator}

In January 1995, the RTGTS was assigned to the T\&P. In fiscal year 1996, the design, fabrication, and testing of the RTGTS, except for fabrication of the third RTG Packaging, was completed. The hardware, except for the third RTG packaging, was delivered to the ultimate system custodian, EG\&G Mound Applied Technologies Inc. In addition, a Certificate of Compliance certifying that the RTG Packaging meets the DOT and NRC requirements for shipments of the General Purpose Heat Source RTG within the U.S. was issued in May 1996.

In fiscal year 1997, T\&P will deliver the third RTG Packaging, pursue issuance of Competent Authority Certification for the RTG Packaging allowing international shipments, complete the program documentation, transfer appropriate program documentation to the system custodian, and provide continuing level-of-effort program support to the custodian and DOE as directed.

\section{Defense Programs}

Enabling Assumption: It is expected that T\&P will participate in approximately three SARP and/or TSRA reviews per year. The endpoint target for each review is a technical data submittal to DOE-AL/NESD that provides the assumptions, analysis, and conclusions of the review.

Work for other Sites

Enabling assumption: It is expected that T\&P will conduct and participate in approximately 20 training classes, site assessments, and/or requests for technical assistance in the automation area per year.

The end-point target for each activity will be the performance of the class at the requesting site or, in the case of an assessment, a written report. 


\section{TRANSPORTATION \& PACKAGING HO SUPPORT Radioisotope Thermoelectric Generator (WBS 5.1.3) \\ and Defense Programs}

FY 1997 Work Plan

WHC-SP-1187

\subsection{Summary-Leve1 Forecasting Data}

Radioisotope Thermoelectric Generator

N/A

\section{Defense Programs}

Packaging Safety Assessment

- to provide methodology and effective criteria for assessing safety and risk associated with transportation activities.

- to provide codes, standards and methodology for conducting confirmatory analys is on packaging designs.

Work for Other Sites

N/A

\subsection{Drivers}

Radioisotope Thermoelectric Generator

The primary regulatory drivers for the development of the RTGTS are 10 Code of Federal Regulations (CFR) 71,49 CFR 173, and DOE Order 460.1. Non-regulatory drivers include the requirements of the RTG User Community.

\subsection{Project Requirements}

\section{Radioisotope Thermoelectric Generator}

There is no long-term life-cycle for this program, as it will terminate at the end of FY 1997.

Management requirements: The T\&P group will continue to provide direct technical and financial management and oversight of design, fabrication, procurement, testing, certification, and program documentation activities associated with the RTGTS. This management and oversight includes any levelof-effort tasks assigned by DOE and also applies to any subcontractor activities. Specifically, the T\&P group will: 


\section{TRANSPORTATION \& PACKAGING HO SUPPORT Radioisotope Thermoelectric Generator (WBS 5.1.3) and Defense Programs}

FY 1997 Work Plan

WHC-SP- 1187

- Direct technical and financial oversight of all program activities and performing subcontractor's efforts. This inciudes maintaining schedule and applicable budget activities as required by T\&P management and DOE guidance.

- Ensure that the RTGTS meets the applicable DOT, NRC, DOE, and RTG User Community requirements and ensure that such compliance is documented.

- Continue the development of the SARP as necessary to obtain the Competent Authority Certification and additional DOE Certifications as necessary. This activity includes coordination and $1 \mathrm{jaison}$ with the DOE Office of Transportation, Emergency Management, and Analytical Services.

- Provide coordination and liaison with the RTG User Community. The objective of this liaison will be to appraise the users of the RTGTS program status and to ensure that the RTGTS conforms to user requirements.

- Provide coordination and liaison with the ultimate system custodian, EG\&G Mound Applied Technologies. The objective of this activity will be to assist the custodian in operating and supporting the RTGTS. This activity is a level-of-effort task.

- Submit monthiy technicai and financial reports to RL.

- Support periodic program update meetings as directed by DOE.

\section{Defense Programs}

Performance packaging evaluates package designs and analysis against regulatory standards, vendor qualifications against specific regulatory criteria and $Q A$ standards, package documentation against requirements, national and international standards and regulatory guides as applicable.

Packaging Safety Assessment evaluates SARPs, risk assessment and NEPA documentation against national and international standards and regulatory guides. 


\section{TRANSPORTATION \& PACKAGING HO SUPPORT Radioisotope Thermoelectric Generator (WBS 5.1.3) and Defense Programs}

\section{FY 1997 Work Plan}

WHC-SP-1187

In addition it includes: proof-testing, performing confirmatory analysis, and conducting comprehensive technical design review.

Management requirements: It is assumed that approximately three SARP/TSRA reviews will take place each fiscal year. Key dates for each fiscal year are approximated as follows:

Submittal of review results for Review \#1: 1/31 Submittal of review results for Review \#2: $5 / 31$

Submittal of review results for Review \#3: $9 / 30$

Conduct reviews of weapons components SARPs and TSRAs in accordance with DOE$\mathrm{AL} / \mathrm{NESD}$ guidance and DOE Order 5610.1 requirements.

\section{Work for Other Sites}

It is assumed in this submittal that approximately 20 training classes, site assessments, technical assistance requests in the automation area will be performed during this reporting period. Key dates and deliverables will depend on the task requested to be performed and needed delivery dates that will be negotiated with the requesting site.

\subsection{Project Issues and Assumptions}

\section{Radioisotope Thermoelectric Generator}

Issues: Although the RTG Packaging has received a Certificate of Compliance for use within the U.S., a Competent Authority Certificate will be pursued by the DOE with the DOT to allow international use in FY 1997. This issue is outside the direct control of T\&P, but T\&P will continue to support this effort as directed in FY 1997.

Assumptions:

- In Fy 1996, per agreement with RL, a communications protocol was established between T\&P and the RTG Community. This protocol allowed T\&P to submit reports and other documentation directly to the DOE Program Monitor electronically for review and then distribute the documents concurrently to the RTG Community and DOE. In addition, direct communication within the scope of work was allowed between T\&P and the RTG User Community. 


\section{TRANSPORTATION \& PACKAGING HO SUPPORT Radioisotope Thermoelectric Generator (WBS 5.1.3) and Defense Programs}

FY 1997 Work P1an

WHC-SP-1187

- Except for the completion and delivery of the third RTG Packaging, al other work in this task for FY 1997 shall be level-of-effort as determined by program requirements and the needs of the DOE and RTG Community in support of the RTGTS.

\section{Defense Programs}

The key assumption for this work plan is that there will be approximately three technical SARP/TSRA reviews in each fiscal year. The actual number of reviews may vary from one to six in each fiscal year, and will vary in complexity.

\section{Work for Other Sites}

The key assumption for this work plan is that there will be approximately 20 HAZMAT classes, site assessment, or technical assistance activities funded during FY 1997 from other DOE site locations. These sites will continue to look to T\&P to provide this expertise to augment their existing staffs and to fill "voids" in areas such as training, where capable HAZMAT instructors and materials may not exist at a particular site. T\&P is also recognized throughout the DOE complex as being a "center of expertise" in the areas of training and automation development and deployment. 


\section{TRANSPORTATION \& PACKAGING HO SUPPORT Radioisotope Thermoelectric Generator (WBS 5.1.3) and Defense Programs}

FY 1997 Work Plan

WHC-SP-1187

\subsection{WORK BREAKDOWN STRUCTURE}

\subsection{WBS Hierarchy}

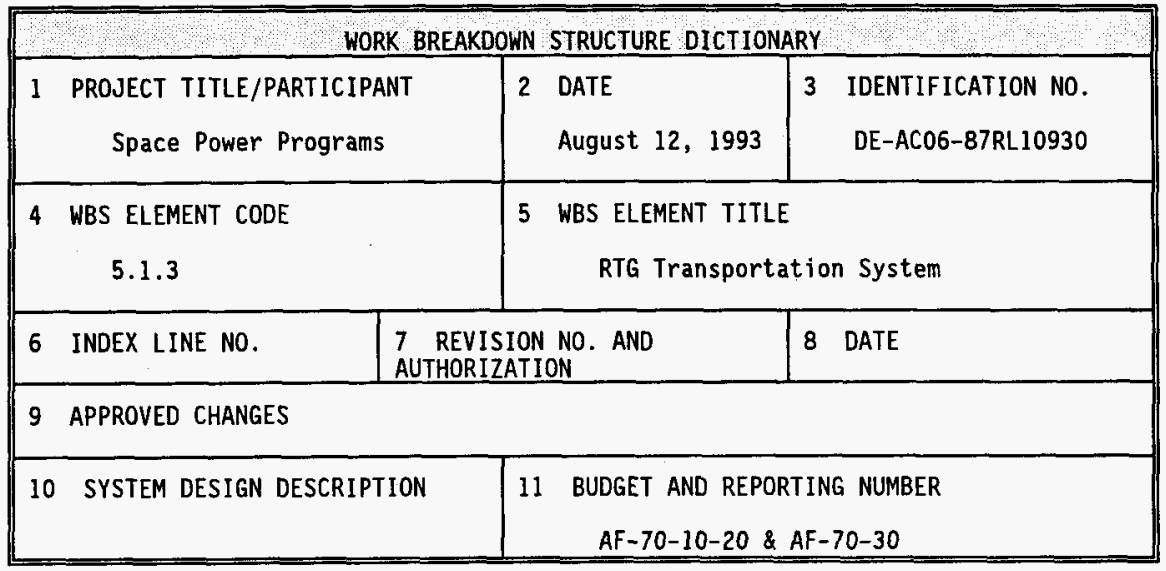

\section{ELEMENT TASK DESCRIPTION}

This program element is for the design, fabrication, testing, certification, and procurement of three shipping packages, two custom semitrailers, and necessary operations and ancillary equipment for the transport of RTGs. It includes the engineering activities needed to meet the technical requirements (thermal, mechanical, shielding, interface, etc.) for shipping RTGs, and the preparation of the Safety Analys is Report for Packaging (SARP) needed to meet regulatory requirements defined in 10 CFR 71 .

The RTG Transportation System Program is divided into three elements:

(1) Program Management, (2) Design/Fabrication, and (3) RTG Contractors. The Design/Fabrication effort is further divided into five elements. These elements are identified as follows:

- System 100 - Systems Engineering 
FY 1997 Work Plan

WHC-SP-1187

- System 120 - Packaging System

- System 140 - Trailer System

- System 160 - Operations and Ancillary Equipment

- System 180 - Facility Transport System

\subsection{WBS RAM}

Radioisotope Thermoelectric Generator

Work Breakdown Structure Index and Programmatic Responsibility Assignment Matrix

\begin{tabular}{|l|l|l|l|l|l|}
\hline $\begin{array}{c}\text { PROGRAM } \\
\text { ELEMENT }\end{array}$ & ACTIVITY & COST ACCOUNT & \multicolumn{1}{|c|}{ TITLE } & \multicolumn{1}{|c|}{$\begin{array}{c}\text { RESPONSIBLE } \\
\text { MAMAGER }\end{array}$} & \multicolumn{1}{|c|}{$\begin{array}{c}\text { RESPONSIBLE } \\
\text { ORGANIZATION }\end{array}$} \\
\hline 5.1 .3 & & & $\begin{array}{l}\text { RTG } \\
\text { TRANSPORTATION } \\
\text { SYSTEM }\end{array}$ & WF IRVINE & T\&P. \\
\hline & 5.1 .3 .1 & $\begin{array}{l}\text { PROGRAM } \\
\text { MANAGEMENT }\end{array}$ & DL MCCALL & T\&P \\
\hline & & $\begin{array}{l}5.1 .3 .1 .1 \\
\text { IXJiO1 }\end{array}$ & $\begin{array}{l}\text { PROGRAM } \\
\text { MANAGEMENT }\end{array}$ & DL MCCALL & T\&P \\
\hline & & $\begin{array}{l}5.1 .3 .2 .1 \\
\text { 6XJ200 }\end{array}$ & $\begin{array}{l}\text { RTG DESIGN \& } \\
\text { FABRICATION }\end{array}$ & JG FIELD & T\&P \\
\hline
\end{tabular}

3.0 SCHEDULE BASELINE

3.1 Program Master Baseline Schedule 


\section{TRANSPORTATION \& PACKAGING HQ SUPPORT Radioisotope Thermoelectric Generator (WBS 5.1.3) and Defense Programs}

Fy 1997 Work Plan

WHC-SP-1187

\subsection{Milestone List}

Radioisotope Thermoelectric Generator

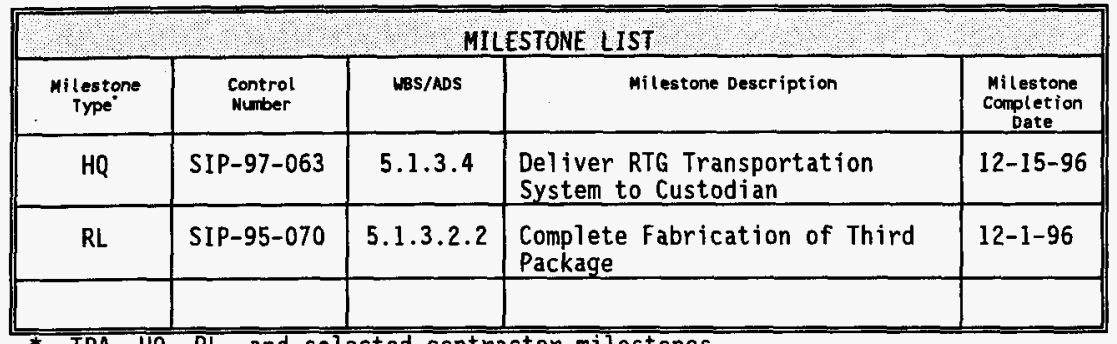

* On Tri-Party Agreement Milestones, aiso designate if they are $\mathrm{HQ}, \mathrm{RL}$ 


\section{TRANSPORTATION \& PACKAGING HO SUPPORT Radioisotope Thermoelectric Generator (WBS 5.1.3) and Defense Programs}

FY 1997 Work Plan

WHC-SP-1187

\subsection{Milestone Description Sheets}

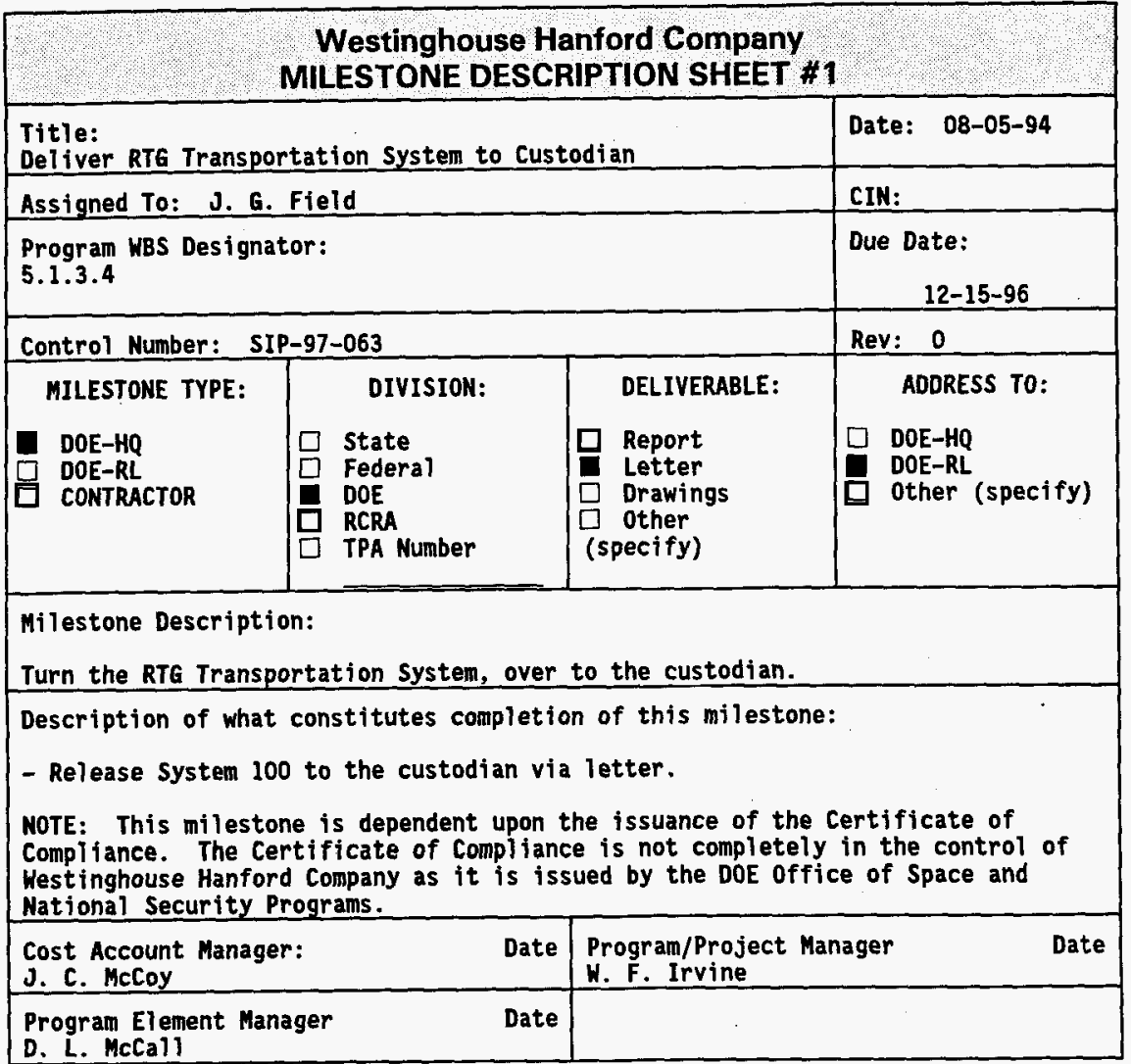




\begin{tabular}{|l|l|}
\hline \multicolumn{1}{|c|}{ Westinghouse Hanford Company } \\
MILESTONE DESCRIPTION SHEET \#2
\end{tabular}


WHC-SP-1187 Rev. 0

4.0 Cost Basellne

4.1

\section{BUDGET AUTHORITY SUMMARY BY YEAR BY ADS}

(\$000s)

\begin{tabular}{|c|c|c|c|c|c|c|c|c|c|c|c|c|c|}
\hline RL WBS * & ADS \# & TITLE & FY1997 & FY1998 & FY1999 & FY2000 & FY2001 & Fr2002 & FY2003 & FY2004 & FY2005 & FY2008 & TOTAL \\
\hline 5.1 .3 & & RTG Program & 361 & 0 & 0 & 0 & 0 & 0 & 0 & 0 & 0 & $x$ & 0 \\
\hline & & Defense Programs & 250 & 263 & 276 & 289 & 304 & 319 & 334 & 351 & 369 & 38 & \\
\hline & & Work for Others & 200 & 206 & 212 & 218 & 224 & 230 & 236.9 & 244 & 251 & 25 & \\
\hline
\end{tabular}

(1) Summary Of All Programmatic ADS's And New B/A (See Exhibit 2); Does Not Include Expense Carryover. 
WHC-SP-1187 Rev. 0

4.1

\section{BUDGET AUTHORITY BY YEAR BY ADS}

(\$000s)

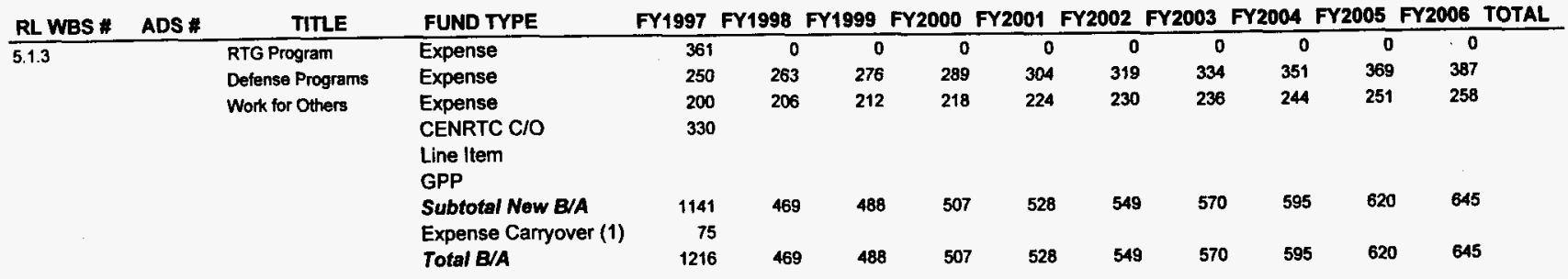

\begin{tabular}{|c|c|c|c|c|c|c|c|c|c|c|}
\hline PROGRAM NEW BIA & 1141 & 469 & 488 & 507 & 528 & 549 & 570 & 595 & 620 & 645 \\
\hline PROGRAM EXPENSE CARRYOVER & 75 & & & & & & & & & \\
\hline PROGRAM TOTAL BIA & 1216 & 469 & 488 & 507 & 528 & 549 & 570 & 595 & 620 & 645 \\
\hline
\end{tabular}

(1) Includes Only Expense Carryover Approved By Site Management Board (SMB) Prior To 10/1/96. 
WHC-SP-1187 Rev. 0

4.1

\section{COST BASELINE BY YEAR BY ADS}

(\$000\$)

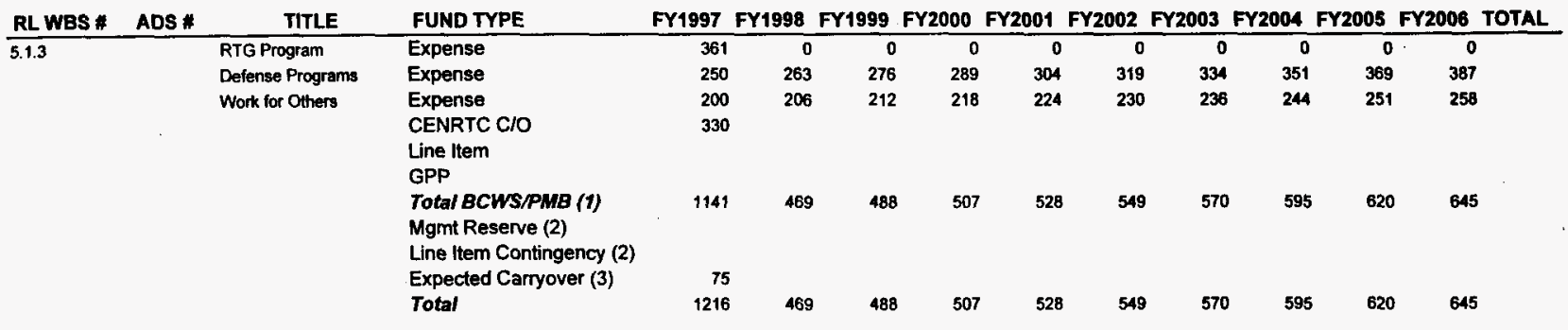

\begin{tabular}{|c|c|c|c|c|c|c|c|c|c|c|}
\hline PROGRAM BCWS/PMB & 1216 & 469 & 488 & 507 & 528 & 549 & 570 & 595 & 620 & 645 \\
\hline PROGRAM TOTAL & 1216 & 469 & 488 & 507 & 528 & 549 & 570 & 595 & 620 & 645 \\
\hline
\end{tabular}

(1) Budgeted Cost Of Work Scheduled (BCWS) Equals Performance Measurement Baseline (PMB).

(2) Management Reserve And Line Item Contingency Held By RL.

(3) Includes Expected Expense Carryover Requested By Formal Change Control In FY1997. 


\section{TRANSPORTATION \& PACKAGING HO SUPPORT Radioisotope Thermoelectric Generator (WBS 5.1.3) and Defense Programs}

FY 1997 Work Plan

WHC-SP-1187

\section{FY 1997 PROGRAM CARRYOVER ( $S$ in 000'S)}

\$330 This carryover is committed to two program areas. The first is workscope carryover for October 1996 for the former WHC, ICF Kaiser, and BCSR support personnel at Hanford. The second is to support completion of the procurement of the third RTG Packaging production unit. Note that the bulk of the carryover was created by the schedule constraints for delivery of the production unit packagings. Additionally, these carryover funds plus the $\$ 361,000$ is the minimum funding requirement to complete the entire scope of work. Funding levels less than this will necessitate a reduction in workscope.

\subsection{Basis of Estimate}

\begin{tabular}{|c|c|c|c|c|}
\hline $\begin{array}{c}\text { Basis of Estimate } \\
\text { WBS Element/Cost } \\
\text { Category }\end{array}$ & & FY 1997 & FY 1998 & FY 1999 \\
\hline \multirow{4}{*}{$\begin{array}{c}\text { WBS } 5.1 .3 \\
\text { RTG }\end{array}$} & $\$$ & $436 \mathrm{~K}$ & 0 & 0 \\
\cline { 2 - 5 } Defense Programs & $\$$ & 3.4 & 0 & 0 \\
\cline { 2 - 5 } & FTE & $250 \mathrm{~K}$ & $250 \mathrm{~K}$ & $250 \mathrm{~K}$ \\
\cline { 2 - 5 } & $\$$ & $200 \mathrm{~K}$ & 2 & 2 \\
\cline { 2 - 5 } Work for Others & FTE & 1.5 & $200 \mathrm{~K}$ & $200 \mathrm{~K}$ \\
\hline \multicolumn{2}{|c|}{ Basis of Estimate (Methodology of estimate and justification of scope) } \\
\hline
\end{tabular}

\section{Radioisotope Thermoelectric Generator}

The estimate included in the carryover is based on the fixed-price contract already negotiated for the completion of the third production unit RTG Packaging. The estimate for the remainder of the workscope is based on an anticipated level-of-effort to complete the remaining program task and provide support to the DOE and custodian for putting the RTGTS into operation. 


\section{TRANSPORTATION \& PACKAGING HO SUPPORT \\ Radioisotope Thermoelectric Generator (WBS 5.1.3) \\ and Defense Programs}

FY 1997 Work Plan

WHC-SP-1187

Defense Programs

The key assumption for this estimate is that there will be approximately three technical SARP/TSRA reviews in each fiscal year.

Work for Others Sites

This estimate was derived from past experience and work history in this area in FY 1995 and FY 1996. 
Exhibit: Program Average FTE Projections by COCS Categories Program WBS/Title: 5.1.3 Radioisotope Thermoelectric Generator

\begin{tabular}{|c|c|c|c|c|c|c|c|c|c|c|c|}
\hline COCS & Title & FY 1997 & FY 1998 & FY 1999 & FY 2000 & FY 2001 & FY 2002 & FY 2003 & FY 2004 & FY 2005 & FY 2006 \\
\hline Co00 & Crafts & & & & & & & & & & \\
\hline $\mathrm{Co10}$ & Carpenters & & & & & & & & & & \\
\hline $\mathrm{CO20}$ & Electricians & & & & & & & & & & \\
\hline $\mathrm{CO30}$ & Heating Air-Conditioning and Refrig Mechanics (HVAC) & & & & & & & & & & \\
\hline $\mathrm{C} 040$ & Machinists & & & & & & & & & & \\
\hline $\mathrm{CO50}$ & Masons & & & & & & & & & & \\
\hline $\mathrm{CO60}$ & Milhwrights & & & & & & & & & & \\
\hline Co70 & Painters & & & & & & & & & & \\
\hline $\mathrm{Co80}$ & Plumbers and Pipefitters & & & & & & & & & & \\
\hline $\mathrm{cog}$ & Structural and Metal Workers & & & & & & & & & & \\
\hline C100 & Vehicle and Mobile Equipment Mechanics & & & & & & & & & & \\
\hline C110 & Welders & & & & & & & & & & \\
\hline C120 & Other Crafts & & & & & & & & & & \\
\hline E000 & Engineers & $2.6 \frac{1}{2}$ & 0.0 & & & & & & & & \\
\hline E010 & Chemical Engineers & & & & & & & & & & \\
\hline E020 & Civil Engineers & 0.75 & 0 & & & & & & & & \\
\hline E040 & Electrical Engineers & & & & & & & & & & \\
\hline E050 & Environmental Engineers & & & & & & & & & & \\
\hline ED60 & Industrial Engineers & & & & & & & & & & \\
\hline E070 & Mechanical Engineers & 0.75 & 0 & & & & & & & & \\
\hline E080 & Nuclear Engineers & 1 & 0 & & & & & & & & \\
\hline E090 & Petroleum/Mining Engineers & & & & & & & & & & \\
\hline E100 & Plant Engineers & 0.1 & 0 & & & & & & & & \\
\hline E110 & Quality Assurance/Control Engineers & & & & & & & & & & \\
\hline E120 & Safety Engineers & & & & & & & & & & \\
\hline E130 & Other Engineers & & & & & & & & & & \\
\hline E140 & Construction Engineers & & & & & & & & & & \\
\hline
\end{tabular}




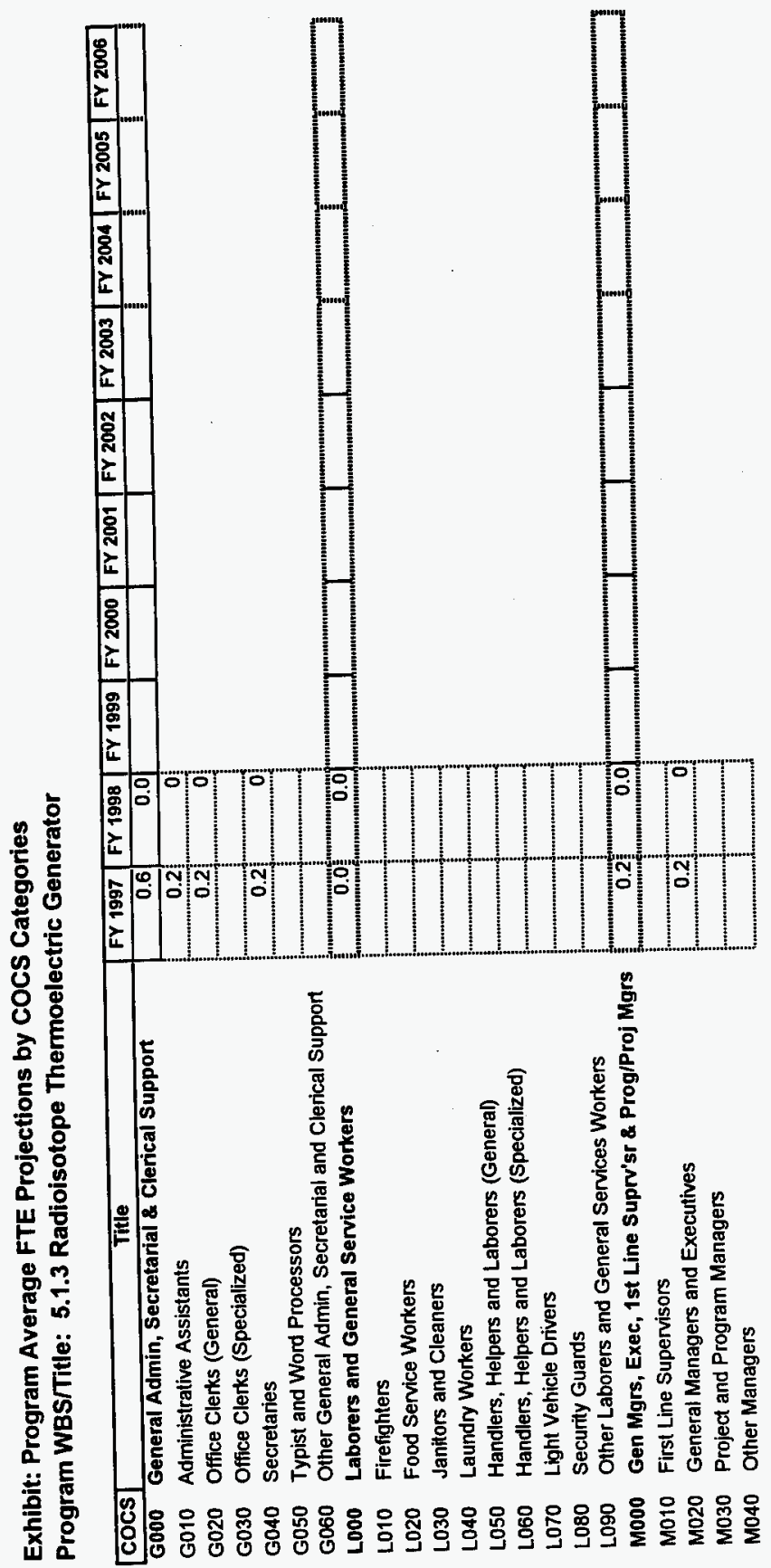




\section{Exhibit: Program Average FTE Projections by COCS Categories Program WBS/Title: 5.1.3 Radioisotope Thermoelectric Generator}

\begin{tabular}{|c|c|c|c|c|c|c|c|c|c|c|c|}
\hline COCs & Title & FY 1997 & $\begin{array}{ll}\text { FY 1998 } \\
\end{array}$ & FY 1999 & FY 2000 & FY 2001 & FY 2002 & FY 2003 & FY 2004 & FY 2005 & FY 2006 \\
\hline$\overline{\mathbf{P 0 0 0}}$ & Professional Administrative \& Related Occupations & 0.0 & 0.0 & & & & & & & & \\
\hline P010 & Accountants and Auditors & & & & & & & & & & \\
\hline P020 & Architects & & & & & & & & & & \\
\hline P030 & Buyers, Procurement and Contracting Specialists & & & & & & & & & & \\
\hline P040 & Communications Specialists & & & & & & & & & & \\
\hline$P 050$ & Compliance Inspectors & & & & & & & & & & \\
\hline P060 & Computer Systerns Analysts & & & & & & & & & & \\
\hline P070 & Cost Estimators and Planners and Schedulers & & & & & & & & & & \\
\hline P080 & Health Physicists & & & & & & & & & & \\
\hline P090 & Industrial Hygienists & & & & & & & & & & \\
\hline P100 & Lawyers & & & & & & & & & & \\
\hline P110 & Personnel and Labor Relations Specialists & & & & & & & & & & \\
\hline P120 & Physicians & & & & & & & & & & \\
\hline $\mathrm{P} 130$ & Physician Assist, Nurses \& Oth Medical Supt Occup'tns & & & & & & & & & & \\
\hline P140 & Safeguards and Other Security Specialists & & & & & & & & & & \\
\hline P150 & Trainers & & & & & & & & & & \\
\hline P160 & Technical Writers, and Editors & & & & & & & & & & \\
\hline$P+70$ & Other Administrative \& Professional Other Occupations & & & & & & & & & & \\
\hline $\mathbf{R} 000$ & Operators & 0.0 & 0.0 & & & & & & 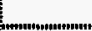 & & \\
\hline R010 & Chemical System Operators & & & & & & & & & & \\
\hline R020 & Drillers & & & & & & & & & & \\
\hline $\mathbf{R} 030$ & Material Moving Equipment Operators & & & & & & & & & & \\
\hline R040 & Nuclear Plant Operators & & & & & & & & & & \\
\hline R050 & Nuclear Waste Process Operators & & & & & & & & & & \\
\hline R060 & Production Systems Operators & & & & & & & & & & \\
\hline R070 & Utilities Operators & & & & & & & & & & \\
\hline R080 & Other Operators & & & & & & & & & & \\
\hline
\end{tabular}


Exhibit: Program Average FTE Projections by COCS Categories Program WBS/Title: 5.1.3 Radioisotope Thermoelectric Generator

\begin{tabular}{|c|c|c|c|c|c|c|c|c|c|c|c|}
\hline Cocs & Title & FY 1997 & FY 1998 & FY 1999 & FY 2000 & FY 2001 & FY 2002 & FY 2003 & FY 2004 & FY 2005 & FY 2006 \\
\hline 5000 & Scientists & 0.0 & 0.0 & & & & & & & & \\
\hline S010 & Chemists & & & & & & & & & & \\
\hline S020 & Environmental Scientists & & & & & & & & & & \\
\hline So3o & Geologists & & & & & & & & & & \\
\hline S040 & Life Scientists & & & & & & & & & & \\
\hline soso & Materials Scientists & & & & & & & & & & \\
\hline s060 & Mathematicians & & & & & & & & & & \\
\hline so70 & Physicists & & & & & - & & & & & \\
\hline S080 & Social Scientists & & & & & & & & & & \\
\hline Sogo & Other Scientists & & & & & & & & & & \\
\hline$\$+00$ & Computer Scientists & & & & & & & & & & \\
\hline TO0O & Technicians & 0.0 & 0.0 & & & & & & & & \\
\hline T010 & Computer Operator/Coders & & & & & & & & & & \\
\hline T020 & Draflers & & & & & & & & & & \\
\hline T030 & Engineering Technicians & & & & & & & & & & \\
\hline T040 & Environmental Sciences Technicians & & & & & & & & & & \\
\hline T050 & Health Physics Technicians & & & & & & & & & & \\
\hline T060 & Industrial Safety and Health Technicians & & & & & & & & & & \\
\hline T070 & Instrument and Control Technicians & & & & & & & & & & \\
\hline T080 & Laboratory Technicians & & & & & & & & & & \\
\hline T090 & Media Technicians & & & & & & & & & & \\
\hline$T 100$ & Survey and Mapping & & & & & & & & & & \\
\hline T110 & Other Technicians & & & & & & & & & & \\
\hline "Total & & 3.4 & 0.0 & & & & & & & & \\
\hline
\end{tabular}




\section{TRANSPORTATION \& PACKAGING HO SUPPORT \\ Radioisotope Thermoelectric Generator (WBS 5.1.3) \\ and Defense Programs}

FY 1997 Work Plan

WHC-SP-1187

\subsection{EXECUTION YEAR}

5.1 Performance Measure Objectives

Radioisotope Thermoelectric Generator Transportation System

This program is not specifically identified in the Project Hanford Contract Request for Proposal.

5.2 Program Performance Baseline Schedule 


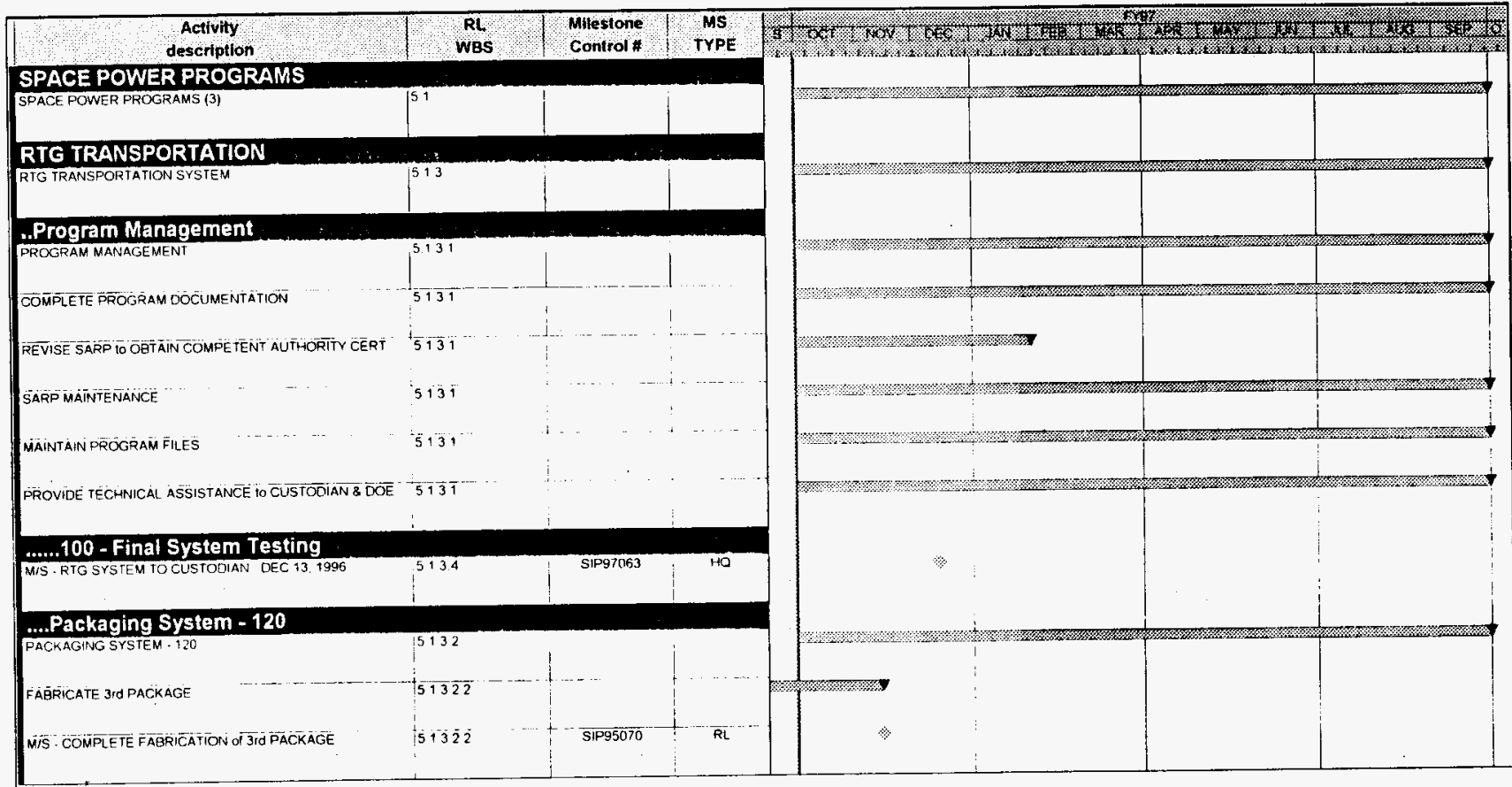

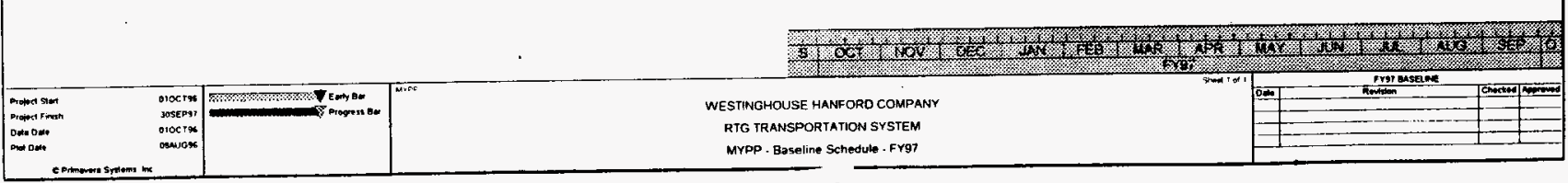

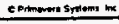


5.3

\section{COST BASELINE FOR EXECUTION YEAR BY PROGRAM BY FUND TYPE BY MONTH}

\begin{tabular}{|c|c|c|c|c|c|c|c|c|c|c|c|c|c|c|c|}
\hline \multirow[b]{2}{*}{ RL WBS \# } & \multirow[b]{2}{*}{ PROGRAM TITLE } & \multirow[b]{2}{*}{ FUND TYPE } & \multicolumn{3}{|c|}{ (\$000s) } & \multirow[b]{2}{*}{ JAN } & \multirow[b]{2}{*}{ FEB } & \multirow[b]{2}{*}{ MAR } & \multirow[b]{2}{*}{ APR } & \multirow[b]{2}{*}{ MAY } & \multirow[b]{2}{*}{ JUN } & \multirow[b]{2}{*}{ JUL } & \multirow[b]{2}{*}{ AUG } & \multirow[b]{2}{*}{ SEP } & \multirow[b]{2}{*}{ TOTAL } \\
\hline & & & OCT & NOV & DEC & & & & & & & & & & \\
\hline \multirow[t]{10}{*}{5.1 .3} & RTG & Expense & 45 & 45 & 45 & 73 & 28.5 & 28.5 & 28.5 & 28.5 & 28.5 & 28.5 & 28.5 & 28.5 & 436 \\
\hline & Defense Programs & Expense & 20.8 & 20.8 & 20.8 & 20.8 & 20.8 & 20.8 & 20.9 & 20.9 & 20.9 & 20.9 & 20.8 & 20.8 & 250 \\
\hline & Work For Others & Expense & 16.6 & 16.7 & 16.7 & 16.7 & 18.7 & 16.7 & 16.7 & 16.6 & 16.7 & 16.6 & 16.6 & 16.7 & 200 \\
\hline & & CENRTC CIO & 330 & & & & & & & & & & & & 330 \\
\hline & & Line Item & & & & & & & & & & & & & \\
\hline & & $\begin{array}{l}\text { GPP } \\
\text { Toto/ BCWS/PMB (1) }\end{array}$ & & & & & & & & & & & & & \\
\hline & & $\begin{array}{l}\text { Total BCWS/PMB (1) } \\
\text { Mgmt Reserve (2) }\end{array}$ & & & & & & & & & & & & & \\
\hline & & $\begin{array}{l}\text { Mgmt Reserve (2) } \\
\text { Line Item Contingency (2) }\end{array}$ & & & & & & & & & & & & & \\
\hline & & Expected Carryover ( 3 & 75 & & & & & & & & & & & & 75 \\
\hline & & Total & 487.4 & 82.5 & 82.5 & 110.5 & 66 & 66 & 66.1 & 66 & 66.1 & 66 & 65.9 & 66 & 1291 \\
\hline
\end{tabular}

\begin{tabular}{|c|c|c|c|c|c|c|c|c|c|c|c|c|c|}
\hline PROGRAM BCWS/PMB & 412.4 & 82.5 & 82.5 & 110.5 & 66 & 66 & 66.1 & 66 & 66.1 & 66 & 65.9 & 66 & 1216 \\
\hline PROGRAM TOTAL & 487.4 & 82.5 & 82.5 & 110.5 & 66 & 66 & 66.1 & 66 & 66.1 & 66 & 65.9 & 66 & 1291 \\
\hline
\end{tabular}

(1) Budgeted Cost Of Work Scheduled (BCWS) Equals Performance Measurement Baseline (PMB).

(2) Management Reserve Held By RL And Line liem Contingency Held By RI.

(3) Includes Expected Expense Carryover Requested By Formal Change Control In FY1997. 
5.4

\section{COST BASELINE FOR EXECUTION YEAR BY PROGRAM BY COST ELEMENT BY MONTH}

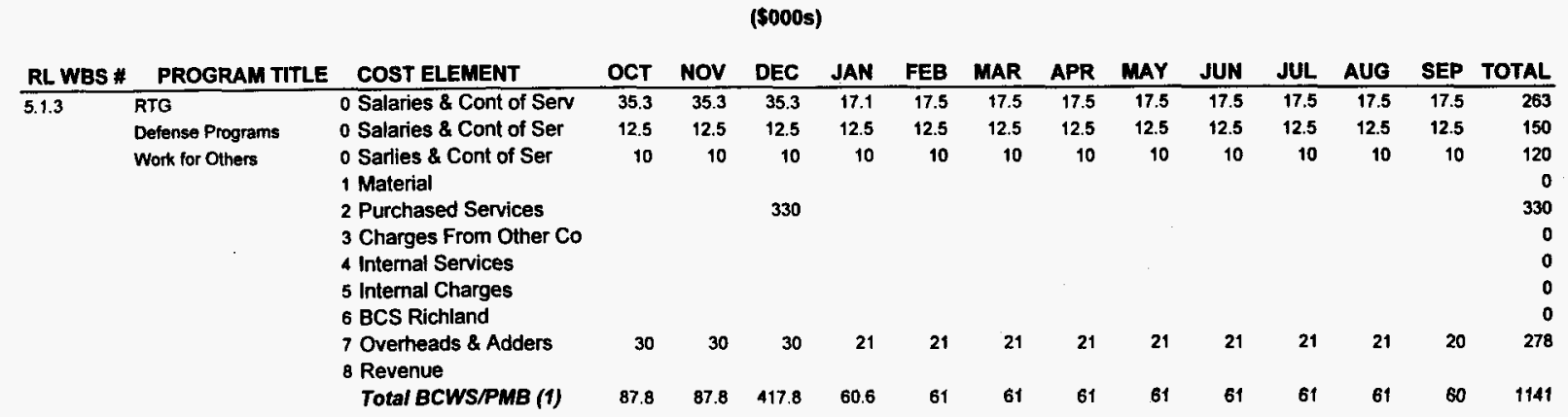




\section{DISTRIBUTION}

Name

Number of Copies

MSIN

T. J. Chapman

D. W. Claussen (RL)

D. M. Eder

J. G. Field

W. F. Irvine

G. W. Jackson

D. L. McCall

J. C. McCoy

J. H. Portsmouth

L. L. Powers

T. K. Teynor (RL)

$57-55$

WHC Central Files

Document Processing Center

A3-88

A3-94

E. F. Mastal (DOE-HQ)

U.S. Department of Energy NE-50/GTN 19901 Germantown Rd.

Germantown MD 20874 